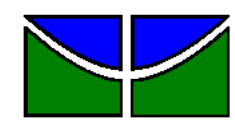

Ciências da Informação e Documentação

Departamento de Administração

ANA CAROLINA GARCIA RODRIGUES LIMA

RESPONSABILIDADE SOCIAL EMPRESARIAL:

Como a sociedade civil e o setor público influenciam as práticas

das empresas

Brasília - DF

2010 
ANA CAROLINA GARCIA RODRIGUES LIMA

\section{RESPONSABILIDADE SOCIAL EMPRESARIAL: \\ Como a sociedade civil e o setor público influenciam as práticas das empresas}

Monografia apresentada ao Departamento de Administração como requisito parcial à obtenção do título de Bacharel em Administração.

Professor Orientador: Prof. Dr. Geraldo Sardinha Almeida 
LIMA, Ana Carolina Garcia Rodrigues.

RESPONSABILIDADE SOCIAL EMPRESARIAL: Como a sociedade civil e o setor público influenciam as práticas das empresas

63: f.: il.

Monografia (Bacharelado) - Universidade de Brasília, Departamento de Administração, 2010.

Orientador: Prof. Dr. Geraldo Sardinha Almeida

1. Administração de empresas 2. Administração Pública 3. Terceiro Setor 4. Responsabilidade Social 


\title{
RESPONSABILIDADE SOCIAL EMPRESARIAL: Como a sociedade civil e o setor público influenciam as práticas das empresas
}

\begin{abstract}
A Comissão Examinadora, abaixo identificada, aprova o Trabalho de Conclusão do Curso de Administração da Universidade de Brasília da aluna:
\end{abstract}

\section{Ana Carolina Garcia Rodrigues Lima}

Prof. Dr. Geraldo Sardinha Almeida Professor-Orientador

Prof. Dr. Antonio Nascimento Junior Professor-Examinador
Prof. Dr. Luiz Fernando Macedo Bessa Professor-Examinador 


\section{RESUMO}

Esta monografia objetiva fazer uma análise do panorama da responsabilidade social, identificar algumas características inerentes às empresas que exercem tais práticas, como elas exercem, assim como o papel do Setor Público e da Sociedade Civil na influência da adoção de práticas de responsabilidade social pelas empresas. A pesquisa prática realizada, entrevistou três empresas do DF que exercem essas atividades, uma possui um Instituto, outra exerce a RSE através de projetos, e a terceira é uma empresa social, que segue a Legislação do Terceiro Setor, ou seja é uma OSCIP. A metodologia utilizada foi uma pesquisa teórica, qualitativa de coleta de dados, opiniões e comparação com a literatura. Com a pesquisa observou-se que poucas empresas utilizam-se dos incentivos fiscais em suas práticas sociais. A empresa analisada, que não possui Instituto e não é OSCIP também não utiliza. O Setor Público influencia as práticas do Terceiro Setor e da responsabilidade social das empresas principalmente através de leis que regulamentam essas atividades, através de parcerias e através das leis de incentivos fiscais. A sociedade civil pode influenciar esta prática de várias maneiras. Como exemplo, quando opta por produtos de entidades socialmente responsáveis, e assim influencia as decisões das empresas ou quando demandam por ações sociais que os governos não conseguem suprir em sua totalidade. 


\section{LISTA DE FIGURAS}

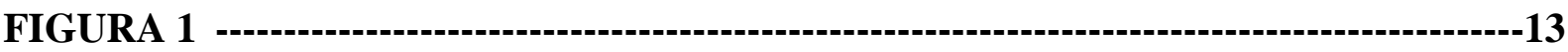

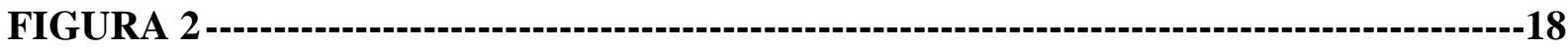

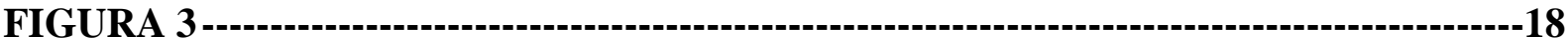

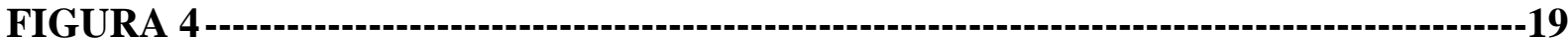

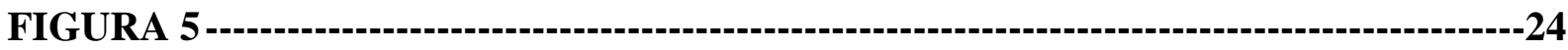

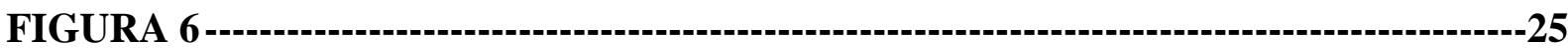

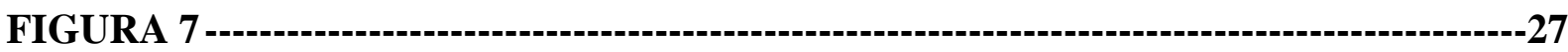

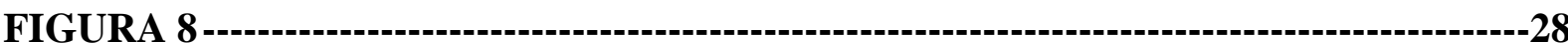

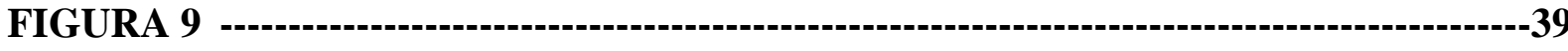

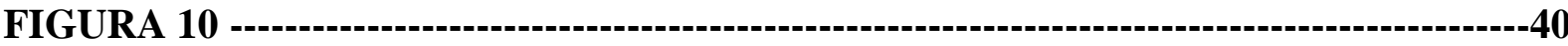

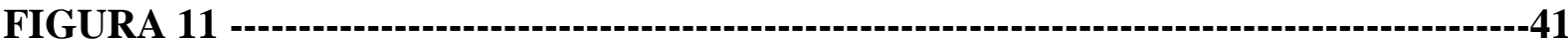

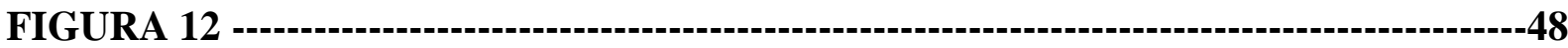

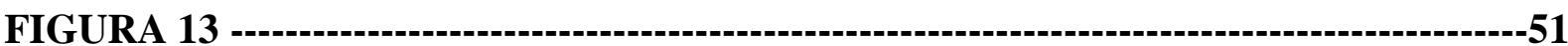




\title{
LISTA DE ABREVIATURAS
}

\author{
AABB - Associação Atlética Banco do Brasil \\ ADVB - Associação dos Dirigentes de Vendas e Marketing \\ BB - Banco do Brasil \\ CNSS - Conselho Nacional do Serviço Social
}

CORTRAP - Cooperativa de Reciclagem, Trabalho e Produção

FBB - Fundação Banco do Brasil

FIA - ou FUNCRIANÇA - Fundo dos Direitos da Criança e do Adolescente

FUNCRIANÇA - Fundo dos Direitos da Criança e do Adolescente

IBASE - Instituto Brasileiro de Análises Sociais e Econômicas

IPEA - Instituto de Pesquisa Econômica Aplicada

ONG - Organização não Governamental

OS - Organização Social

OSCIP - Organizações da Sociedade Civil de Interesse Público.

PIB - Produto Interno Bruto.

PROUNI - Programa Universidade para todos.

RSE - Responsabilidade Social Empresarial

SENAC - Serviço Nacional de Aprendizagem Comercial

SEBRAE - Serviço Brasileiro de Apoio às Micro e Pequenas Empresas.

SERPRO - Serviço Federal de Processamento de Dados. 


\section{SUMÁRIO}

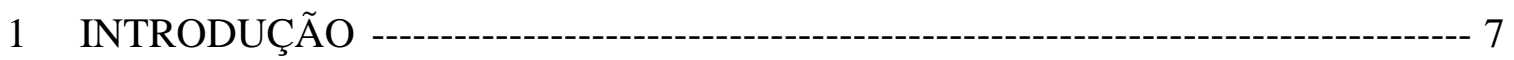

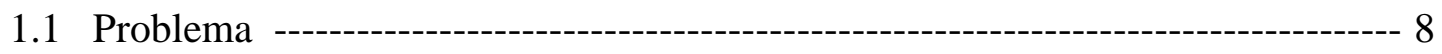

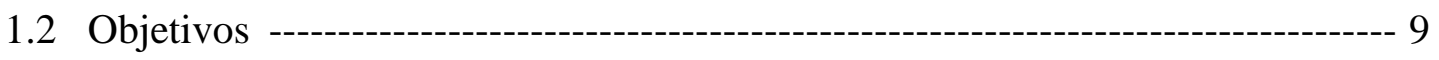

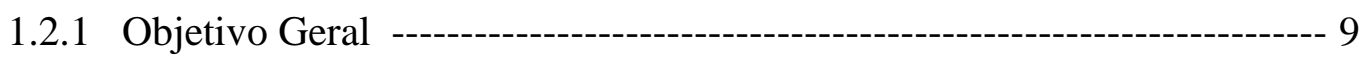

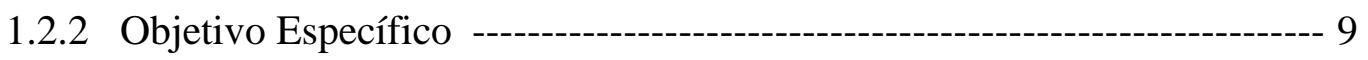

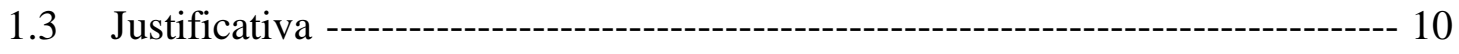

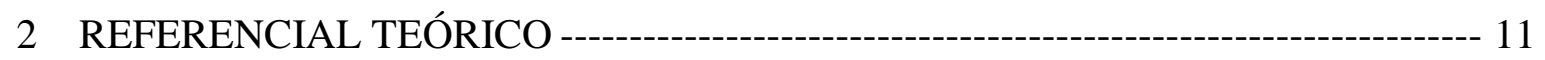

2.1 Panorama da Responsabilidade Social ---------------------------------------------- 11

2.2 Características das empresas que investem em responsabilidade social ---------- 17

2.3 Influência da Sociedade Civil e do Setor Público nas práticas de Responsabilidade

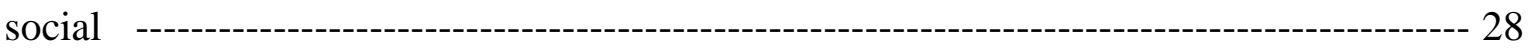

\section{MÉTODOS E TÉCNICAS DE PESQUISA}

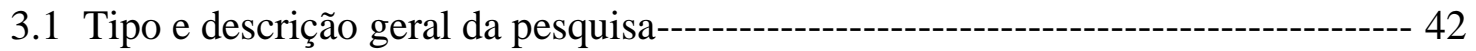

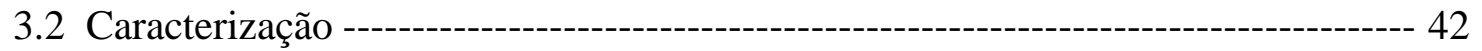

3.3 Participantes do Estudo------------------------------------------------------------------ 43

3.4 Caracterização do Instrumento de pesquisa ----------------------------------------- 43

3.5 Procedimentos de coleta e análise de dados --- 43

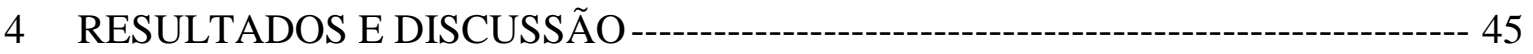

5 CONSIDERAÇÕES FINAIS ---10 54

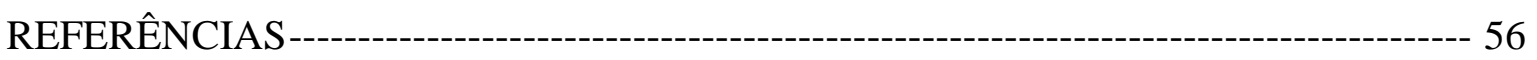




\section{INTRODUÇÃO}

Os termos responsabilidade social-ambiental, práticas sócio- responsáveis, empresa cidadã, Terceiro Setor, Fundações, Institutos, ONGs, OSCIPs, etc., estão cada vez mais difundidos no meio empresarial e na sociedade como um todo. A cada ano aumenta o número de estudos, análises, e empresas querendo estudar e colocar em prática alguma ação que beneficie não somente a sociedade e a comunidade em que estão inseridas, mas também, e porque não, sua marca e sua imagem diante da sociedade.

Com as diferenças sociais existentes em países em desenvolvimento como o Brasil, as empresas sentem necessidade de tomarem uma atitude, aplicando parte de seu lucro em projetos que contribuam para a melhoria da qualidade de vida das pessoas, dos funcionários e da preservação do meio ambiente. As empresas movimentam a economia mundial, e grande parte da renda gerada encontra-se nas mãos de algumas delas. Não seria o ideal esperar que somente os governos adotassem medidas de desenvolvimento social, visto que muito do dinheiro existente no mundo pertence a essas empresas. Cabe a elas também, o papel na contribuição do desenvolvimento dos países.

As práticas de responsabilidade social colaboram, em parte, na diminuição de alguns problemas que os governos não conseguem, pelo menos em curto prazo resolver, ou simplesmente não tem a iniciativa de desenvolver. Também é fato que somente o Estado/Setor Público não conseguiria sozinho suprir algumas demandas, principalmente em países que existem altas taxas de problemas sociais e desigualdades. A sociedade civil então, se adianta, e procura alguma forma de amenizar ou solucionar problemas, seja ela mesmo desempenhando essas atividades, seja cobrando das empresas, tanto em âmbito local, regional e nacional.

Muitas pessoas provavelmente não teriam acesso à educação, às artes, à cultura, à saúde, à habitação, enfim, a uma oportunidade de crescimento pessoal e profissional se não fosse o trabalho social destas empresas. Muitos, se não tivessem essas oportunidades, oferecidas por essas ONGs, por esses Institutos, ou Fundações não teriam, o emprego que possuem, a renda, a formação acadêmica, etc. É vantajoso, economicamente, investir no desenvolvimento social das pessoas. Quanto mais renda a pessoa tiver mais ela compra das mesmas empresas que, quem sabe, ajudaram no seu desenvolvimento pessoal.

Como diria Henry Ford: "Pagando pouco aos homens, preparamos uma geração de crianças subalimentadas e subdesenvolvidas, tanto física quanto moralmente. Teremos uma 
geração de trabalhadores fracos de corpo e espírito que, portanto, se mostrará ineficaz quando entrar na indústria, que pagará a conta”

As empresas, portanto, ao investirem em responsabilidade social, estão preparando seus funcionários, consumidores e admiradores de amanhã.

Com essa tomada de consciência várias empresas de todos os portes estão procurando cada vez mais, colaborar de acordo com suas receitas. As de grande porte como as do setor financeiro, construção civil, varejo, etc., formam seus próprios institutos ou fundações, fazem doações às ONGs, entidades como creches, asilos, centros de convivência, etc., patrocinam projetos esportivos, culturais, educacionais entre outros. As médias, pequenas e micro empresas também têm colaborado cada vez mais, na medida de suas possibilidades, incentivando o voluntariado entre seus funcionários, fazendo doações, criando projetos, ou até mesmo institutos, entre outras atividades.

O Setor público pode incentivar essas atividades através de algumas ações. Entre elas estão os incentivos fiscais previstos em leis, concedidos a organizações que investem em determinados projetos de cunho social, cultural, esportivo, educacional, sem fins lucrativos. Algumas dessas leis surgiram na década de 1990, década na qual, a responsabilidade social no Brasil deu um salto importante e aumentou significantemente sua atividade. Existem também leis que regulamentam as atividades do Terceiro Setor, das organizações sem fins lucrativos, como exemplo as Leis: ${ }^{\circ}$ 9532/97 , $n^{\circ} 9637 / 98$ e a n ${ }^{\circ}$ 9.790/99.

As empresas além de usufruírem desses benefícios, obtém um maior reconhecimento de seus steakholders, como fornecedores, comunidade, clientes, funcionários, etc.

O estudo da realidade das atividades de responsabilidade social empresarial e o papel do Setor Público e da sociedade civil no desenvolvimento dessas práticas é o foco principal deste trabalho.

\subsection{Problema}

A reação que o empresariado possui aos incentivos fiscais é um fator importante no estudo e análise das práticas do Terceiro Setor, assim como o papel do Setor Público, seja regulamentando ou incentivando tais práticas. Isto deve ser analisado e entendido para melhor conhecimento da realidade das empresas acerca deste tema.

A união do segundo setor (representado pelas empresas) e o terceiro setor (entidades sem fins lucrativos que fomentam práticas socialmente responsáveis) é de suma importância 
para o desenvolvimento pessoal de funcionários, de comunidades, das pessoas que usufruem dos programas, projetos, oferecidos, enfim da sociedade em geral. Com isso a sociedade civil, pode influenciar as práticas socialmente responsáveis das empresas na medida em que observa e até exige que elas adotem atitudes socialmente responsáveis.

Os governos conseguem por si mesmos, sanar todos os problemas sociais existentes nos países em desenvolvimento em que a desigualdade social ainda é grande? Elas não solucionarão todos os problemas sociais, mas colaborarão com o Estado, complementando políticas públicas de educação, saúde, esportes, cultura, entre outras. Lembrando que a responsabilidade social empresarial somente complementa a ação social desenvolvida pelo Estado, e em algumas regiões, cidades, comunidades, etc. ela colabora para o desenvolvimento local.

O estudo da influência do setor público e da sociedade civil nas práticas sociais das empresas é importante para que se tenha conhecimento das verdadeiras motivações das empresas no desempenho dessas práticas. A análise das características das empresas que "abraçam" causas sociais e ambientais, e como elas fazem isto, também é importante para o conhecimento de programas e projetos mais comumente exercidos pelo empresariado

\subsection{Objetivo}

\subsubsection{Objetivo Geral}

Estudo e análise da responsabilidade social empresarial e da influência do Setor Público e da sociedade civil nesta prática, através da visão dos empresários e da literatura existente.

\subsubsection{Objetivo Específico}

Análise da literatura existente acerca da responsabilidade social, principalmente da empresarial, estudo de características de atividades exercidas pelas empresas, e pelas organizações de Terceiro Setor mantidas pelas empresas, quais ações são desempenhas e por quem, e como o setor público e sociedade civil podem incentivar as práticas socialmente responsáveis, assim como a análise, através de entrevistas, da visão do empresariado brasiliense acerca destes aspectos. 


\subsection{Justificativa}

A análise das práticas de responsabilidade social, e principalmente destas práticas pelas empresas é importante para que alunos de administração e também de outros cursos, além de professores, universidades, empresas, enfim, a sociedade em geral, tenha consciência de que estas práticas devem ser bem formuladas, implementadas e avaliadas.

Quem não leva em consideração a responsabilidade social em sua empresa, está provavelmente à mercê das boas práticas de gestão e por assim dizer, das práticas de marketing, que são cada vez mais necessárias, em tempos de competição acirrada entre as empresas.

Estudar os benefícios que as empresas podem usufruir para exercerem tais práticas, como os incentivos oferecidos pelo Estado através de leis, e como as empresas utilizam esses incentivos é importante, para a análise mais detalhada de fatores que levam ou não as empresas a exercerem atividades de cunho social e/ou ambiental. Os consumidores, a comunidade, a sociedade civil no geral, também influenciam essas práticas? Vale a pena ser uma empresa socialmente responsável? Os Incentivos governamentais são atrativos, a sociedade influencia mesmo as decisões empresariais sobre responsabilidade social? Com este estudo pretende-se analisar estes fatores.

Também a análise das características das empresas que adotam ações de responsabilidade social, e também a análise de projetos, trabalhos, programas. etc.; por elas desenvolvidos é de grande valor para o conhecimento da realidade do Terceiro Setor empresarial no Brasil.

Após estas análises, o trabalho profissional ou voluntário no mercado do Terceiro Setor, principalmente empresarial, através de suas fundações, institutos, projetos, programas, etc., será visto e desempenhado de uma maneira mais clara e eficaz. 


\title{
2 REFERENCIAL TEÓRICO
}

\subsection{Panorama da responsabilidade Social}

Pinto e Lara (2004) escreveram que o marco no campo da responsabilidade social foi o lançamento do livro Responsibility of the Businessman, de Howard Bowen, nos Estados Unidos em 1953.

Contudo o termo ainda não está totalmente consolidado e, portanto, pode ser considerado como "em construção", visto que suscita uma série de interpretações. (ASHLEY, 2002; MOHR e WEBB, 2001 apud PINTO e LARA, 2004 p. 50)

Duarte e Dias (1986) apud Lima (2008) citou que as primeiras manifestações relacionadas à responsabilidade social surgiram no inicio do século, com trabalhos de Charles Eliot (1906), Arthur Hakley (1907) e John Clark (1916), mas na época essas manifestações não tiveram muito aceitação por soarem heresias socialistas...

\begin{abstract}
... Oliver Sheldon em 1923 defendeu a inclusão entre as preocupações da empresa de outros objetivos além do lucro dos acionistas.[...] Duarte e Dias (1986) também falam que em 1975 centenas de dissertações e teses doutorais já existiam sobre o tema, demonstrando o crescente interesse da comunidade acadêmica sobre o assunto. $\mathrm{Na}$ Europa as idéias de responsabilidade social chegam no final da década de 60 , e na década de 70 surgem os primeiros estudos significativos. [...] e ainda na década de 70 as idéias de responsabilidade social chegam aos países do chamado capitalismo periférico.
\end{abstract}

No Brasil, Ashoka e McKinsey \& Company (2006) escreveram que a origem da atuação organizada da sociedade civil e do setor social, setor que abrange as práticas de responsabilidade social exercidas pelas empresas, terceiro setor, atividade das ONGs, OSCIPS, etc., remonta à filantropia, presente no Brasil desde o século XVI com o surgimento das santas casas de misericórdia.

...primeiramente eram regidas pela lógica assistencialista e sustentadas por ricos filantropos. Somente no final do século XIX, com a intensificação da atuação do Estado na área social, que começaram a se insinuar mudanças na forma de organizar e administrar essas instituições. Com a crescente industrialização e urbanização da sociedade, essas instituições passaram a depender economicamente do Estado e a seguir sua orientação administrativa e financeira (p.10).

Ashoka e McKinsey \& Company (2006) continuam que o crescente número de operários, que migraram para as cidades, fizeram aumentar também os problemas sociais, e conseqüentemente o número de organizações sem fins lucrativos. Vinculadas ao Estado elas buscavam amenizar os problemas causados pela pobreza e a exclusão social. 
Já Pinto e Lara (2004) escreveram que a doutrina da responsabilidade social representa uma transformação na concepção da empresa e de seu papel na sociedade, uma vez que se fundamenta em uma nova visão da realidade econômica. [...] A responsabilidade social é um relacionamento ético e responsável da empresa com os grupos de interesse que influenciam sua atuação ou são por elas impactados - sociedade, clientes, etc., bem como o respeito a questões ambientais e investimentos em ações sociais (PINTO e LARA, 2004).

É importante citar o termo Balanço Social, descrito por Trevisan (2002), que se preocupa com as atividades da empresa em relação à sociedade externa, englobando vários steakholders, entre eles os clientes, investidores, fornecedores e governo. [...] a comunicação desonesta de Balanços Sociais certamente será identificada pelo mercado como hipócrita, e a empresa terá sua marca seriamente prejudicada. Trevisan (2002) continua que ser socialmente responsável não é ser assistencialista porque essa prática não minimiza as dificuldades de uma pessoa nem de uma comunidade.

Em relação à análise do balanço social nas empresas Trevisan (2002) faz um histórico desta prática: a companhia alemã Steag foi a primeira empresa, em 1971, a produzir uma espécie de relatório sobre suas atividades sociais.

Porém o que pode ser classificado como um marco na história dos balanços sociais, no seu sentido pleno, aconteceu na França em 1972: a empresa Singer fez o, assim chamado primeiro Balanço Social da história das empresas [...] até que em 1977, foi aprovada uma lei que tornava obrigatória a realização de balanços sociais periódicos para todas as empresas com mais de 300 funcionários [...] O primeiro Balanço Social feito no Brasil foi da Nitrofértil, empresa estatal situada na Bahia, em 1984. No mesmo período, estava sendo realizado o Balanço Social do Sistema Telebrás, publicado em meados da década de 1980. (TREVISÁN 2002 p. 5).

Maignan (1999) apud Pinto e Lara (2004) salienta também que o fato de que, embora alguns autores considerem cidadania corporativa e performance social corporativa como sinônimos, diferenças podem ser observadas.

A performance social corporativa investigaria questões morais, gerenciais e
sociológicas, a cidadania corporativa focalizaria atividades mais restritas
desenvolvidas pela organização com o escopo de atender a demandas sociais mais
concretas (p.51).

É importante salientar estudo de Carroll (1991) apud Pinto e Lara (2004) que propõe quatro faces para a cidadania corporativa: econômica, legal, ética e filantrópica. A figura 1 apresenta essas dimensões: 


\begin{tabular}{|l|l|}
\hline \multicolumn{1}{|c|}{ DIMENSÕES } & \multicolumn{1}{|c|}{ SIGNIFICADO } \\
\hline Econômica & $\begin{array}{l}\text { A dimensão econômica incluiria as obrigações da empresa em ser produtiva, lucrativa e atender às } \\
\text { expectativas dos acionistas de obter retorno sobre o investimento. Todos os outros papéis dos negó- } \\
\text { cios são atributos derivados desse pressuposto fundamental }\end{array}$ \\
\hline Legal & $\begin{array}{l}\text { A dimensão legal requer que o negócio acrescente à sua missão econômica um respeito às leis e aos } \\
\text { regulamentos. A sociedade espera que os negócios ofereçam produtos dentro das normas de seguran- } \\
\text { ça e obedeçam a regulamentações governamentais }\end{array}$ \\
\hline Ética & $\begin{array}{l}\text { A dimensão ética leva em consideração princípios e padrões que definem a conduta aceitável determi- } \\
\text { nada pelo público, órgãos regulamentadores, grupos privados interessados, concorrentes e a própria } \\
\text { organização. A tomada de decisões deve ser feita considerando-se as consequêencias de suas ações, } \\
\text { honrando o direito dos outros, cumprindo deveres e evitando prejudicar os outros }\end{array}$ \\
\hline Filantrópica & $\begin{array}{l}\text { A dimensão filantrópica prevê que o negócio deve estar envolvido com a melhoria da sociedade por } \\
\text { meio da responsabilidade legal, ética e econômica, bem como a adoção de práticas filantrópicas. } \\
\text { Prevê também atividades que são guiadas pelo desejo dos negócios em se engajar em papéis sociais } \\
\text { não legalmente obrigatórios, mas que estão se tornando cada vez mais estratégicos }\end{array}$ \\
\hline
\end{tabular}

Fonte: Carroll (1991); Carroll (1998); Maignan \& Ferrell (2001a) apud Pinto e Lara (2004)

Figura 1 - Significado das quatro dimensões da cidadania corporativa segundo Carroll (1991)

Continuando, Melo e Froes (2001) apud Veiga Neto et al. (2004) escreveram que a economia do terceiro setor gira em torno de indicadores sócio-econômicos internos e externos. Outra característica desse setor segundo esses autores é a capacidade de gerar novos conhecimentos...

... e de contribuir para o aumento da empregabilidade e a capacitação profissional de pessoas, através de seus inúmeros programas voluntários em comunidades. Esses programas possuem uma atuação segmentada proporcionando relacionamentos personalizados com uma imagem altamente positiva, podendo atuar nas áreas de Cultura e recreação; assistência social; educação; saúde; desenvolvimento e defesa de direitos; religião e ambientalismo. [...] Pode-se acrescentar moradia, alimentação e nutrição, saneamento, segurança, trabalho, emprego e renda, reforma agrária e previdência social (p.3).

Já Mânica (2005) citou os três setores da sociedade. O terceiro Setor seria a área dentro da qual se encontram todas as entidades que não fazem parte do Estado e do mercado. Fazem parte do terceiro setor as entidades que detenham, cumulativamente as seguintes características:

- Natureza privada;

- Ausência de finalidade lucrativa;

- Institucionalizadas;

- Auto- administradas; e

- Voluntárias.

Mânica (2005) continua que as entidades que visam um beneficio mútuo, seja ele artístico, cultural, social ou esportivo, desde que não possuam como função principal a obtenção de lucro financeiro, fazem parte do Terceiro Setor. [...] O autor também cita Ruth 
Cardoso que conceituou Terceiro Setor como um espaço de experimentação de novos modelos de pensar e agir sobre a realidade social.

Sua afirmação tem grande mérito de romper com a dicotomia entre o público e o privado, na qual o público era sinônimo de estatal e o privado, de empresarial (p.5)

Machado (2006) também definiu o Terceiro Setor. Segundo ele é o conjunto de atividades privadas com fins públicos e sem fins lucrativos, composto por instituições civis de qualquer origem - religiosa, comunitária, institutos e fundações empresariais, ONGs, etc.; diferenciando-se da lógica do Estado e de mercado.

Ruth Cardoso (2000) apud Machado (2006), escreveu que foi o americano John D. Rockfeller quem cunhou a expressão terceiro setor, publicando em 1975 o primeiro estudo detalhado sobre a importância das iniciativas empresariais com sentido público.

Rockfeller apud Ruth Cardoso (2006): "refiro-me a um setor menos visível do que
o normalmente dominante no mundo dos negócios e do governo [...]; o terceiro
setor - constituído por organizações e associações não-governamentais e sem fins
lucrativos - continua a ser como uma terra incógnita, quase inexplorada no que
diz respeito a sua dinâmica interna, suas motivaçães e suas relações sociais,
econômicas e políticas com o resto do mundo. Na verdade, é no seio desta esfera
institucional que quase toda a contribuição filantrópica-doaçôes e voluntariado-
se transforma em ação de ajuda, ou seja, bens e serviços para os beneficiários
finais". (MACHADO 2006 p. 103)

Veiga Neto et al. (2004) escreveram também sobre os três setores da sociedade. O primeiro que é representado pelo governo; o segundo setor que opera o mercado, e corresponde à livre iniciativa e usa o lucro como instrumento, definindo a agenda econômica e o terceiro setor que corresponde às instituições com práticas sociais, sem fins lucrativos e são entre outras as OSCIPs, entidades beneficentes, centros sociais, etc.

Já Ribeiro et al. (2001) escreveram sobre o conceito de cidadania empresarial que está diretamente ligado a toda ação de Responsabilidade Social, exercido pelas empresas. Esse é o novo conceito que confere às empresas uma nova imagem empresarial.

Uma empresa cidadã é reconhecida através de ações de interesse público, suprindo e atenuando suas carências, e assim gerando o reconhecimento, a confiança e o respeito dos consumidores. [...] A promoção da cidadania e o desenvolvimento sustentável da comunidade é tarefa principal da empresa cidadã.

Ribeiro et al. (2001) também citam que as empresas podem criar uma entidade, juridicamente independente, como fundações, associações ou desenvolverem ações sociais de forma estruturada e sistemática, através de parcerias com OSCIPs.

"Uma fundação é um tipo especial de pessoa jurídica, pois pode ser constituída a partir da decisão de um só individuo. Sua constituição se dá, em um primeiro momento, pela reunião de bens e a sua destinação a uma finalidade determinada pelo instituidor" (SZAZI 2000 apud RIBEIRO ET AL. 2001). Rezende (1997) apud Ribeiro et al. (2001) define fundação como "um conjunto de bens, com um fim determinado, que a lei atribui a condição de pessoa" (p.12). 
Já Gonçalves (1980) escreveu que a idéia e que a otimização do lucro não pode permanecer o objetivo único das atividades da empresa; a empresa existe para o cumprimento de objetivos de natureza econômica e de natureza social.

Daqui se infere que ela deve sempre desempenhar essas duas funções nunca dissociadas, mas pelo contrário perfeitamente integradas: a função econômica, geradora de produtos e lucro, e a função social, geradora de bem-estar no seu conceito mais amplo (p.60)

Interessante também citar Stephen Kanitz, que em seu site cita os dez mandamentos da responsabilidade social. Resumidamente ele cita entre outras coisas que contrariando os preceitos da administração que exige pesquisar primeiro o mercado antes de sair criando novos, na área social estes princípios muitas vezes são jogados fora.

A maioria dos projetos começa nos departamentos de marketing das empresas sem consultar as entidades que são do ramo. O espírito do terceiro setor é "servir o outro", e isto significa perguntar primeiro: “o que vocês precisam?" [...] As empresas brasileiras estão dedicando em média $1 \%$ do lucro ao social, o que corresponde a $0,1 \%$ das receitas.

Kotler e Keller (2005) já abrangem outra visão da responsabilidade social empresarial. Segundo eles o marketing socialmente responsável deve atacar em três frentes: a do comportamento legal, ou seja, cumprir a lei, e delimitar o que são práticas ilegais, anti-sociais, ou anti-competitivas; do comportamento ético: corresponderia a definição clara do código de ética da empresa, criação de uma tradição de comportamento ético na organização e do comportamento de responsabilidade social: a empresa deve possuir uma consciência social, ou seja, desenvolver programas na área social e/ou ambiental.

Continuando com Coutinho e Soares (2002) que escreveram que, devido ao agravamento de problemas sociais por todo o planeta, entre estes problemas pode-se citar: desemprego, exclusão, poluição, etc. e à dificuldade dos governos em solucioná-los, as forças da sociedade estão passando por um processo de reorganização, as empresas assim, estão passando a adotar uma postura mais socialmente responsável. Todos esses fatores sociais, influenciam nas práticas das empresas. A sociedade e seus problemas, requerem uma atitude mais positiva das instituições que possuem maiores condições de assumirem programas, doações, projetos, etc. visando uma melhoria social das comunidades e da sociedade.

Coutinho e Soares (2002) continuam:

A responsabilidade social corporativa baseia-se na noção de que as corporações possuem a obrigação de trabalhar para a melhoria do bem-estar social (Frederick, 1994). Wartick e Cochram (1985). Elencam as duas premissas centrais deste conceito: $1^{\circ}$ - existe um contrato entre a organização e a sociedade, que funciona como um veiculo por meio do qual o comportamento dos negócios é posto em conformidade com os objetivos da sociedade; $2^{\circ}-$ os negócios desempenham o papel de agentes morais dentro da sociedade, refletindo e reforçando seus valores (p.78). 
Coutinho e Soares (2002) também escreveram que algumas empresas vêm relatando mudanças em suas relações comerciais, em função de sua atuação socialmente responsável, ocorrendo até mesmo um aumento em seu poder de barganha com fornecedores. Vale lembrar também que os consumidores estão mais conscientes, as informações atualmente correm mais rápido e em mais quantidade. Os clientes, consumidores, podem assim analisar e escolher melhor se querem comprar um produto de uma empresa socialmente responsável ou não. Certamente em condições de preço e qualidade semelhantes o consumidor optará pelo produto da empresa que é socialmente responsável.

Machado (2006) também escreveu que a conduta socialmente responsável das empresas vai além das esferas econômica/ética/legal, mas engloba também o engajamento em projetos sociais (responsabilidade discricionária), com isso recursos são alocados para atividades que não estão diretamente relacionadas com negócios imediatos da empresa. Isso é encarado sobre três aspectos:

- Pode advir de valores dos acionistas, que independentemente do retorno que as atividades sociais podem trazer, fazem questão de que a empresa se engaje socialmente. É uma visão benigna da atuação da empresa na sociedade.

- Podem ser determinadas por uma visão pragmática. As práticas de alguma forma trariam benefícios para a empresa, seria uma estratégia de busca de valor. Parte do pressuposto que o capital social reputacional das empresas tende a crescer com ações sociais.

- Podem derivar de gestores que vêem nessa prática uma forma de obter ganhos pessoais, poder, autoridade na comunidade local, independentemente de haver alinhamento com os interesses da organização. [...] Constitui um problema de governança, pois existe desalinhamento de interesses entre o gestor e os principais acionistas. (MACHADO 2006).

Importante também citar Reetz e Tottola (2006) que escreveram sobre as motivações que levam as empresas a serem responsáveis socialmente:

- Novas preocupações e expectativas dos cidadãos, autoridades públicas, consumidores, investidores;

- Critérios sociais que possuem uma influência crescente sobre as decisões individuais ou institucionais de investimento na qualidade de consumidores ou investidores;

- Preocupação crescente em relação aos danos causados ao meio ambiente pelas atividades econômicas;

- Transparência nas atividade empresariais, impulsionadas pelos meios de comunicação social e pela tecnologia (REETZ e TOTTOLA 2006). 


\begin{abstract}
À semelhança da gestão da qualidade, a responsabilidade social de uma empresa deve ser considerada como investimento, não como encargo. Por meio dela, é possível adaptar uma abordagem inclusiva do ponto de vista financeiro, comercial e social, conducente a uma estratégia em longo prazo que minimize os riscos decorrentes de incógnitas. As empresas deverão assumir responsabilidades sociais em qualquer ambiente em que estejam inseridas, aplicando o principio ao longo de toda a sua cadeia de produção (REETZ e TOTTOLA 2006 p. 19).
\end{abstract}

Reetz e Tottola (2006) também escrevem que a responsabilidade social de uma empresa ultrapassa a sua própria esfera e estende-se à comunidade local, envolvendo além de trabalhadores e acionistas, parceiros comerciais, fornecedores, clientes, autoridades públicas e ONGs. [...] As empresas contribuem para a vida das comunidades locais em termos de emprego, remuneração, benefícios e impostos.

\title{
2.2 Características das empresas que investem em responsabilidade social
}

Segundo Souza e Nassif (2008) o final do século XX foi marcado por grandes transformações na vida social, política e econômica. A sobrevivência das organizações em tempos de competição acirrada depende do balanceamento de suas ações nas esferas econômica, social e ambiental.

Almeida (2002) apud Souza e Nassif (2008) continuam que devido à melhoria do nível educacional da sociedade e o aumento de um público consumidor mais informado, a pressão da sociedade sobre as organizações tem aumentado, fazendo com que elas se tornem mais responsáveis.

Sá (2003) escreveu que existem empresas que patrocinam e apóiam instituições sem esperar nada em troca, apenas pela conscientização de que a iniciativa privada e a própria sociedade são também responsáveis pelo desenvolvimento do país.

Noleto (2000) apud Veiga e Neto et al. (2004) escreveu que as parcerias e alianças estratégicas entre o segundo e o terceiro setor vêm se consolidando gradativamente à medida que expandem as organizações da sociedade civil e aumentam as demandas sociais e de intervenção na sociedade.

Vassallo (2000) apud Veiga Neto et al. (2004) argumenta que essas ações tratam de interesses em valores, crenças e visões de futuro. Essas empresas não deixaram de buscar excelência de seus produtos, mas utilizam-se de táticas de comunicação e marketing social para o alcance de maiores lucros. Ele ainda afirma que com o aumento dos desafios gerados pela concorrência, essas empresas perceberam que o grande diferencial está na descoberta progressiva de que o lucro, produtividade e imagem da marca apenas serão conquistados por empresas que apresentem perfil socialmente responsável. Peruzzo (1999) apud Veiga e Neto et al. (2004) afirma que o interesse público nas estratégias das empresas nos últimos anos se dá porque existem interesses obscuros que fazem parte de suas estratégias de marketing (p.5). 
Veiga Neto et al. (2004) afirmam também que praticamente todos os setores praticam ações sociais, uns mais outros menos, mas praticam:

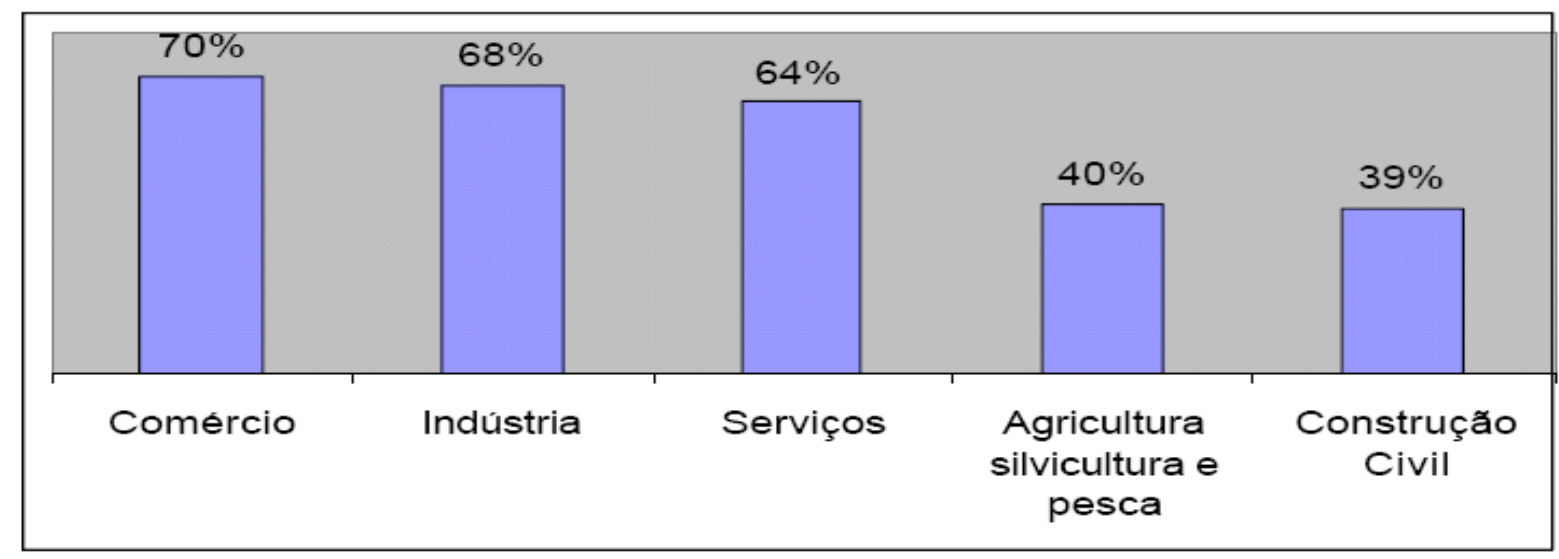

Fonte: Pesquisa IPEA (2000) apud Veiga Neto et al. (2004)

Figura 2: Responsabilidade social em empresas privadas e sua relação com o terceiro setor.

A participação das empresas em termos de valores é proporcional às suas características, quanto maior a empresa maior a contribuição social. Entretanto há tendência de envolvimento também das micros, pequenas e médias empresas na responsabilidade social (VEIGA NETO et al. 2004).

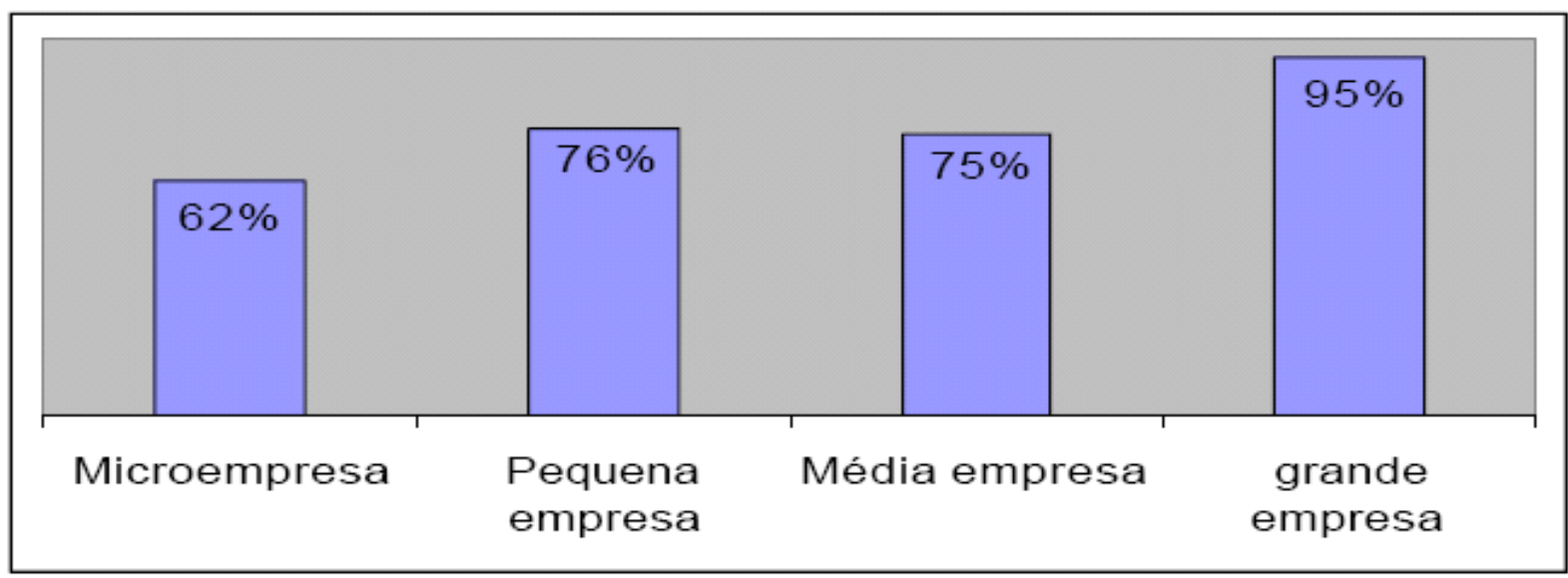

Fonte: Pesquisa IPEA apud VEIGA NETO et al. (2004)

Figura 3: Participação das empresas em ações sociais no Brasil.

Sá (2003) escreveu que a ADVB - Associação dos Dirigentes de Vendas e Marketing do Brasil - havia divulgado uma pesquisa sobre a atuação das organizações em programas de responsabilidade social, compilando dados de um universo de pouco mais de 2000 empresas...

... em todo o país. Os resultados foram animadores já que mais de $90 \%$ das empresas pesquisadas disseram adotar programas de cunho social voltados para a comunidade. Infelizmente, das centenas de empresas pesquisadas, apenas $9 \%$ eram de pequeno porte. Muitas não sabem como praticar a responsabilidade social ou 
acham que não conseguirão realizar grandes projetos por não disporem de verba suficiente (p.2).

No site do Instituto Ethos, consta uma estatística de quantas empresas praticam a responsabilidade social levando em consideração o porte das mesmas, das 1368 empresas praticantes de responsabilidade social vinculadas ao Instituto Ethos tem-se os seguintes números:

\begin{tabular}{|c|c|c|}
\hline PORTE & TOTAL & $\%$ \\
\hline Micro Empresa & 290 & $21,20 \%$ \\
\hline Pequena Empresa & 380 & $27,78 \%$ \\
\hline Média Empresa & 254 & $18,57 \%$ \\
\hline Grande Empresa & 444 & $32,46 \%$ \\
\hline Não Informado & 0 & $0,00 \%$ \\
\hline
\end{tabular}

Fonte: http://www.ethos.org.br/sistemas/empresas_entidades/empresas_associadas/lista_geral/index.asp Figura 4: Porte das empresas associadas ao Instituto Ethos 2010. Reprodução total.

Ashoka e McKinsey \& Company (2006) continuam que nos anos 1990, surgiu uma nova tendência: a mobilização e o envolvimento de empresas privadas em questões sociais. Em um primeiro momento elas buscaram selecionar e financiar causas e instituições com as quais se identificassem, sem uma lógica definida e sem avaliações de resultados de impacto.

\footnotetext{
Em seguida, à medida que foram ganhando experiência na área, algumas dessas empresas passaram a constituir suas próprias fundações e institutos, com o objetivo de tornar seu investimento social mais estratégico. [...] $\mathrm{O}$ engajamento das empresas no setor social resultou no surgimento de uma nova fonte de recursos para as ações sociais, com influências, significativas nos processos até então existentes (p. 11-12)
}

O Instituto Ethos (2000) escreveu que a busca de excelência pelas empresas tem como objetivos a qualidade nas relações e a sustentabilidade econômica, social e ambiental. A atuação baseada em princípios éticos elevados e a busca de qualidade nas relações são manifestações da responsabilidade social empresarial. [...] Empresas socialmente responsáveis estão melhor preparadas para assegurar a sustentabilidade a longo prazo dos negócios.

Instituto Ethos (2000) também cita que a empresa é socialmente responsável quando vai além da obrigação de respeitar as leis, pagar impostos e observar as condições adequadas de segurança e saúde para os trabalhadores. [...] A responsabilidade social empresarial é um tema de grande relevância nos principais centros da economia mundial.

Nos Estados Unidos e na Europa proliferam os fundos de investimento formados por ações de empresas socialmente responsáveis. O Sustainability Index, da Dow Jones, por exemplo, enfatiza a necessidade de integração dos fatores econômicos, ambientais e sociais nas estratégicas de negócios das empresas. Normas e padrões 
certificáveis relacionados especificamente ao tema da responsabilidade social, como as normas SA8000 (relações de trabalho) e AA1000 (diálogo com partes interessadas), vêm ganhando crescente aceitação. No Brasil, o movimento de valorização da responsabilidade social empresarial ganhou forte impulso na década de 90, através da ação de entidades não governamentais, institutos de pesquisa e empresas sensibilizadas para a questão. O trabalho do Instituto Brasileiro de Analises Sociais e Econômicas - IBASE, na promoção do Balanço Social é uma de suas expressões e tem logrado progressiva repercussão (p.3).

Bufoni et. al. (2009) escreveram sobre as duas certificações AA1000 e SA8000. A primeira, AA1000, tem como objetivo "melhorar a transparência e o desempenho das organizações, aumentando a qualidade de seus relatórios sociais" (O'Dwyer 2001 apud Bufoni et. al. 2009), ela é padrão voluntário para os processos de contabilização, auditoria e evidenciação ética e social. A segunda, SA8000, oferece enfoque mais holístico do desenvolvimento sustentável, com diretivas que consistem em: selagem social de produtos, padrões de evidenciação social corporativos; condições de trabalho, etc. A SA8000 ainda é pouco conhecida no Brasil. Esses certificados assim como outros existentes e não citados nesse trabalho, influenciam também, as empresas a praticarem de uma maneira mais coerente a responsabilidade social/ambiental, inclusive avaliando melhor as conseqüências sociais das práticas por elas desenvolvidas.

Vergara e Branco (2001) citaram exemplo de empresas adeptas da responsabilidade social e como elas contribuem com a sociedade, adotando praticas relacionadas à educação, combate à violência etc. Do setor financeiro foi citado o BankBoston, que à época praticava ações significativas, e em parceria com o Sindicato dos Bancários de São Paulo, criou o Projeto Travessia, o qual buscava levar crianças e jovens que viviam nas ruas de volta aos seus lares e também dar a elas o acesso a educação. Empresas como a Caixa Econômica (empresa pública), e a privada Empresas Pires colaboravam com o projeto além de outras.

Outro exemplo citado por Vergara e Branco (2001) é a Coca Cola que também tem investido em educação. Com o Programa Coca Cola de valorização do Jovem ela tem contribuído com o combate à evasão escolar e já foi inclusive aceito como um dos integrantes do projeto Acorda Brasil do Ministério da Educação, programa que se baseia no monitoramento escolar feito por jovens entre 15 e 17 anos com seus colegas das $7^{\circ}$ a $9^{\circ}$ séries. (VERGARA e BRANCO 2001).

Vergara e Branco (2001) citam também a Natura que incentiva seus funcionários e suas consultoras a desenvolver e comercializar cartões, embalagens e camisetas cujos recursos arrecadados são destinados ao financiamento de projetos de melhoria do ensino público. [...] As Cerâmicas Portobello, também tem investido na área social, principalmente da cidade onde a sua fábrica está situada; com o envolvimento da prefeitura local e da Caixa Econômica 
Federal, o projeto Alamandas, possibilita o acesso à casa própria para muitos de seus empregados; a empresa doa os terrenos cabendo à prefeitura a realização das obras de infraestrutura (VERGARA e BRANCO 2001).

Também é interessante observar o caso do SENAC, citado no mesmo trabalho de Vergara e Branco (2001): cerca de 100 empresas na época do estudo estavam envolvidas no Programa de Educação para o Trabalho em que quatro mil adolescentes carentes entre 14 e 18 anos receberam entre 1997 e 2001 algum tipo de formação técnica.

As empresas para exercerem a responsabilidade social precisam acima de tudo serem lucrativas. Com determinada verba extra, fica obviamente mais fácil desenvolver programas socialmente responsáveis. Elas assim geram mais empregos, implantam novas unidades e conseqüentemente favorecem a economia. [...] As empresas são agentes de mudanças quando suas atividades provocam transformações no meio em que atuam. (RIBEIRO et al. 2001). Este é com certeza um dos interesses dos governos, que a economia não desaqueça e que novos empregos sejam criados.

Stephen Kanitz em seu site também critica que a quase totalidade das empresas que criaram institutos com a marca da empresa fogem de problemas sociais complicados, como abuso sexual, prostituição infantil, alcoolismo, drogados, mães solteiras, pais abusivos, entre outros. Ele argumenta que são projetos que não se adequam a boa imagem que a empresa quer passar de sua marca. [...] Empresas que criaram institutos ou fundações com a marca da empresa, preferem projetos como educação, adolescentes, esportes e ecologia.

Cabe ressaltar que o motivos dessas escolhas, poderia ser na verdade a maior demanda que esses serviços de educação e saúde requerem.

A seguir cinco exemplos de empresas que investem em responsabilidade social.

A primeira o Banco do Brasil, empresa de economia mista, que através da FBB Fundação Banco do Brasil exerce atividades sociais e ambientais. Segundo o site da Fundação Banco do Brasil sua missão é mobilizar, articular, desenvolver e gerir ações sustentáveis de inclusão e transformação social, contribuindo para a promoção da cidadania. Em 2008, cinco grupos temáticos faziam parte dos trabalhos da FBB: ações de grupos de funcionários voluntários do Banco do Brasil, Desenvolvimento Regional Sustentável, Comunicação, Assistência Técnica e Extensão Rural e Reciclagem. (RELATÓRIO DE GESTÃO 2009FBB).

Os objetivos estratégicos do Banco do Brasil ao investir em responsabilidade social através da FBB são segundo seu relatório de 2009: 1 quanto à imagem constitucional: ser reconhecida pela promoção da inclusão digital, democratização do acesso à informação, ser 
reconhecida também como instituição que valoriza, incentiva, dissemina e reaplica tecnologias sociais, etc. $2^{\circ}$ Quanto à forma de atuar: desenvolver, promover e implementar iniciativas no âmbito da economia solidária, entre outros. $3^{\circ}$ Quanto o relacionamento do BB - Banco do Brasil com os funcionários: promover ações integradas e sinérgicas com os princípios de responsabilidade socioambiental assumidos pelo BB, etc. (RELATÓRIO DE GESTÃO 2009 - FBB)

No ano de 2008, a FBB destinou investimentos sociais para a execução de projetos vinculados aos seguintes programas estruturados: banco de tecnologias sociais; AABB - Associação atlética dos funcionários do Banco do Brasil - Comunidade; BB Educar; Inclusão Digital; Memória Documental; Trabalho e Cidadania e reaplicação de tecnologias sociais. (RELATÓRIO DE GESTÃO 2009 FBB)

A segunda empresa é o Bradesco - empresa do ramo financeiro privado, uma das maiores do Brasil. Através de sua Fundação Bradesco, ela exerce atividades sociais, principalmente na área da educação.

\begin{abstract}
A Fundação Bradesco oferece a educação básica em suas etapas: educação infantil, ensino fundamental, e o ensino médio, na modalidade regular e de educação de jovens e adultos. [...] $\mathrm{O}$ respeito às diferenças e às atitudes solidárias, pautam as relações entre professores e alunos, alunos e alunos e demais profissionais da escola, com o intuito de construir a concepção cidadã que guiará as relações sociais dentro e fora da escola. (FUNDAÇÃO BRADESCO 2010)
\end{abstract}

Em Brasília existe uma escola da Fundação Bradesco em Ceilândia, ela foi fundada em 1986, e oferece ensino fundamental, médio, técnico profissionalizante, formação inicial e continuada de trabalhadores e ainda Curso de Educação de jovens e adultos, via teleducação, além da alfabetização de jovens e adultos. [...] Comunidades próximas ou distantes a essas escolas são também beneficiadas, por meio de programas de voluntariado, centros de inclusão digital, etc.

Em 2009 a Fundação atendeu cerca de 431.000 pessoas, sendo 108.825 alunos, em suas escolas próprias. Nos centros de inclusão digital foram mais de 320.000 atendimentos no mesmo ano. (FUNDAÇÃO BRADESCO 2010)

A terceira empresa é do Distrito Federal e entorno, com filiais também no estado da Bahia e de Goiás - os laboratórios Sabin, empresa privada que possui o Instituto Sabin, que é uma pessoa jurídica de direito privado, sem fins lucrativos, e de interesse público. Segundo o site da empresa (2010) o Instituto tem entre suas diretrizes contribuir para a implementação de políticas nas áreas de saúde, cultura, esporte, educação e meio-ambiente; articulação e orientação na atuação de responsabilidade social dos seus mantenedores; etc.

O Instituto Sabin é uma OSCIP, que coordena e articula a atuação social das empresas mantenedoras nas áreas de: saúde, qualidade de vida, educação e cultura. 


\begin{abstract}
Os recursos utilizados pelo Instituto para a realização de suas ações são provenientes das empresas mantenedoras: Laboratório Sabin de Analises Clinicas e Sabinbiotec, de contribuições espontâneas de pessoas físicas e jurídicas, e de instituições parceiras que incentivam o trabalho da empresa. O Instituto realiza patrocínios desde que relacionados com as finalidades constantes em seu estatuto. [...] Atende indiretamente ONGs, creches, abrigos e associações com as quais mantêm parceria. (INSTITUTO SABIN).
\end{abstract}

A Cooperforte é uma cooperativa de crédito atuante em Brasília. Ela pratica a responsabilidade social, através do Instituto Cooperforte, uma OSCIP. A partir do ano 2000 as campanhas realizadas pelo Instituto se tornaram mais consistentes, e dois anos mais tarde um projeto mais estruturado surgiu com o nome de Passaporte do Futuro, que promoveu capacitação profissional em informática e inserção profissional de quarenta jovens de Brasília. Em 2008 o número de beneficiados já era de trezentos e dezoito jovens neste programa, aqui no Distrito Federal. (INSTITUTO COOPERFORTE).

Em 2007 foi criado o programa Passaporte Solidário, cujos projetos objetivam a promoção e o desenvolvimento local sustentado de comunidades. O instituto tem como parceiros o SEBRAE nacional, a Fundação Banco do Brasil, Serpro, Fundação Ulbra, entre outras empresas. O Instituto também possui um projeto chamado Ecoeficiência, que incentiva os funcionários da Cooperforte e do Instituto a adotarem práticas ecossustentáveis no ambiente de trabalho. (INSTITUTO COOPERFORTE).

Desde a fundação em março de 2003, até dezembro de 2008, os programas do Instituto Cooperforte já beneficiaram, segundo seu site, 63,6 mil pessoas, direta e indiretamente, e foram investidos cerca de $\mathrm{R}$ \$ 5,3 milhões, aplicados em 104 projetos. As regiões mais beneficiadas foram a Nordeste, Sudeste e Centro-Oeste. (INSTITUTO COOPERFORTE)

Por fim, a empresa Corpore BR, que trabalha com gestão em ativos imobiliários. A empresa pratica a responsabilidade social valorizando o folclore nacional. Em parceria com um projeto chamado Sacizal dos Pererês ela incentiva a preservação e a valorização do folclore e culturas nacionais, utilizando-se de personagens do folclore como educadores da conscientização sustentável. O Sacizal dos Pereres, conta com o patrocínio da Corpore BR para realizar um dia cultural, com oficinas de brinquedos recicláveis, pintura, música, minhocultura. etc. Esse dia ocorre todos os anos em 31 de outubro. (CORPORE BR).

Em abril de 2007, a Corpore BR também assinou sua adesão ao Pacto Global tornando-se uma das signatárias do compromisso no Brasil. Essa adesão significa comprometimento da empresa com os dez princípios propostos pela Organização das Nações Unidas. Também a empresa aderiu à campanha "Todos Juntos Trabalhando para Salvar a Terra" que incentivou a coleta seletiva de materiais recicláveis destinando esses materiais às 
cooperativas de catadores. Desde 2007 essa campanha tem muito sucesso no edifício Corporate Financial Center em Brasília, já tendo destinado 65 toneladas de papéis e derivados à CORTRAP - Cooperativa de Reciclagem, Trabalho e Produção, colaborando com a manutenção do trabalho e renda de aproximadamente 120 famílias. Também a empresa se tornou parceira do Clube da Semente do Brasil, uma ONG que trabalha com a conscientização da preservação das espécies arbóreas da flora brasileira e a elevação da qualidade de vida humana. A Corpore BR distribui sementes por meio de material de divulgação e marketing (CORPORE BR)

Continuando com a literatura sobre esse tema, Peliano (2009) em pesquisa do IPEA observou que as experiências de avaliação de práticas sociais pelas empresas ainda são muito recentes e restritas a um grupo de empresas de maior porte, que nem sempre disponibilizam relatórios completos das metodologias utilizadas e dos resultados obtidos.

O impacto que tais empresas exercem na sociedade é de fato existente, mas a maioria das empresas por não possuir uma avaliação consistente de tais ações não tem como provar com dados concretos esse impacto. Peliano (2009) explicita isso: no Brasil somente 16\% do universo das empresas que atuam no social, declararam possuir algum tipo de avaliação documentada das ações sociais realizadas.

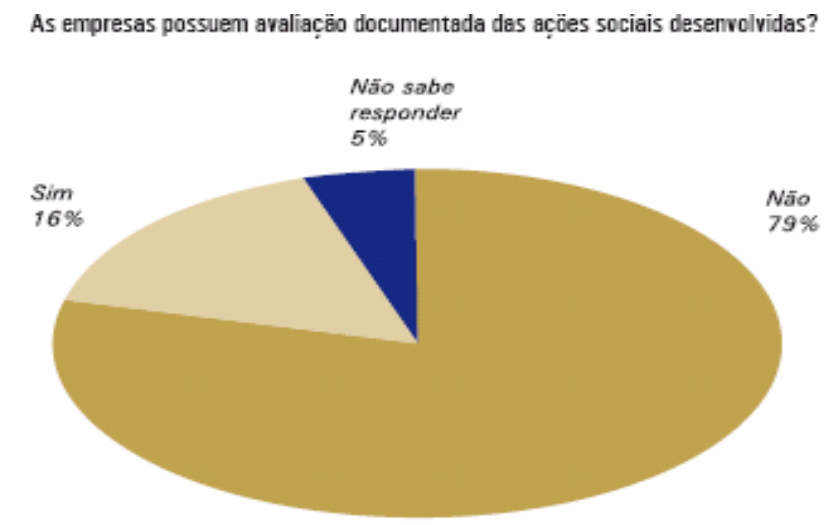

Fonte: Pesquisa Ação Social das Empresas no Brasil (Disoc/IPEA, 2006) apud Peliano (2009 p. 28) Figura 5: As empresas possuem avaliação documentada das ações sociais desenvolvidas?

Peliano (2009) mostra o porquê que as empresas que avaliam suas ações sociais investem em responsabilidade social, assim como a motivação das empresas que não avaliam suas ações: 


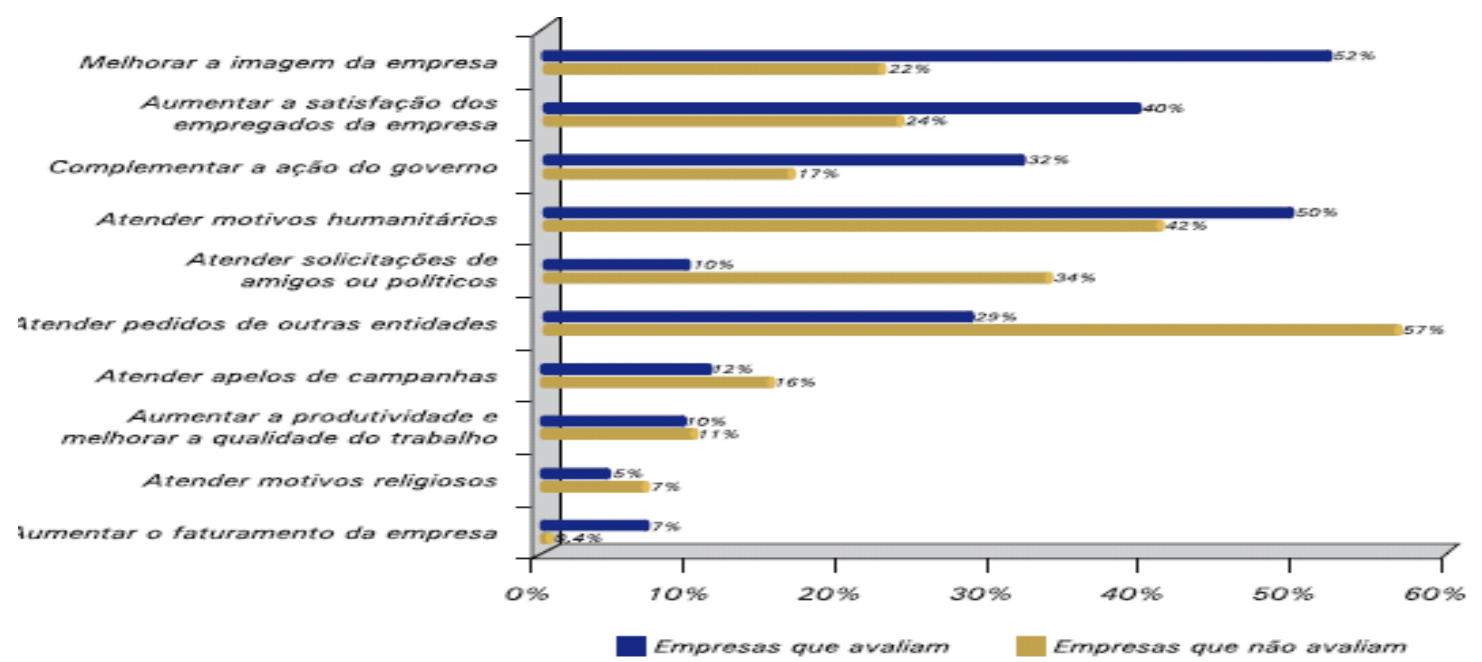

Fonte: Pesquisa Ação Social das Empresas no Brasil - Disco/IPEA (2006) apud Peliano (2009). Tabulações especiais (2008) - Empresas com mais de 500 empregados.

Figura 6: Por quais motivos as empresas realizam ações sociais?

O principal objeto de estudo dessa monografia não é o estudo da avaliação das ações sociais praticadas pelas empresas. Mas é importante citar tal gráfico para observar em parte o que motiva as empresas a realizarem tais ações. $O$ fator mais importante são os benefícios governamentais, entre eles os fiscais? Ou os benefícios oriundos da exposição da marca da empresa?

Cresce o interesse das empresas em serem publicamente identificadas pela defesa de causas sociais. Para tanto, vêm tomando ciência de que necessitarão de mais do que declarações de princípios para mostrar à sociedade o seu compromisso efetivo. As pressões externas podem não estar sendo explicitadas, mas, de alguma forma, estão influindo nas decisões de avaliar. [...] As empresas fazem opção previa por uma causa de reconhecida importância no país e posteriormente, buscam informações gerais que possam ajudar na implantação dos programas ou projetos relacionados ao tema selecionado. Então, com base em informações secundárias e debates internos ou com especialistas, definem o que fazer e onde intervir. Em seguida, colhem informações mais especificas, diagnósticos mais detalhados sobre o público alvo e, eventualmente, potenciais parceiros locais. São essas informações que facilitam as avaliações posteriores. (PELIANO 2009 p. 46 e p 55).

Outro fator que contribui para que as empresas pratiquem a responsabilidade social é a diferenciação de marca. Não só preocupações humanitárias levam os empresários a investir no social; Peliano (2001) continua esse argumento, dizendo que compensa economicamente.

Melhora a relação da empresa com seus parceiros e a imagem diante dos consumidores, cada vez mais interessados em empresas responsáveis social e ecologicamente. É um diferencial de marca, e a imagem socialmente responsável abre uma oportunidade para entrarem em mercados restritos e atingir novos nichos mercadológicos. [...] Entre as atitudes empresariais que estimulam os consumidores a comprar seus produtos ou recomendá-los aos amigos está, em primeiro lugar, a contratação de portadores de deficiência; em segundo a colaboração com escolas, postos de saúde e entidades sociais da comunidade; e em terceiro a manutenção de cursos de alfabetização para funcionários e familiares. Esses dados foram obtidos através de uma pesquisa do Instituto Ethos e o jornal Valor Econômico junto a consumidores brasileiros. (PELIANO 2001 p. 26) 
As empresas ao escolherem quem vão beneficiar socialmente levam em consideração alguns critérios, entre alguns exemplos Peliano (2001) cita:

- Critérios Objetivos: conhecimento dos problemas da comunidade, entidade que apóia; grau de organização da comunidade; pobreza/carência; projeto-modelo capazes de atrair parceiros; qualidade/sustentabilidade dos projetos; etc.

- Critérios Pessoais e afetivos: indicações de amigos e pedidos políticos e/ou de familiares; motivos religiosos; sensibilidade a pedidos de entidades; etc. (PELIANO 2001).

Queiroz (2000) também cita o termo "cidadania empresarial". Martinelli (1998) apud Queiroz (2000) escreveu que dentro da sociedade o setor empresarial é o detentor do maior acervo de recursos potencialmente mobilizáveis e as empresas podem relacionar-se com a sociedade assumindo diferentes posturas.

\begin{abstract}
A empresa cidadã seria aquela que adota a posição proativa de querer contribuir para encaminhar soluções para os problemas sociais. Segundo Rhoden, o conceito de cidadania empresarial encampa a noção de co-responsabilidade da empresa pelos problemas da sociedade, e define como empresa-cidadã aquela que não foge aos compromissos de trabalhar para a melhoria da qualidade de vida de toda a sociedade (p.2).
\end{abstract}

Já Almeida (2007) escreveu que as empresas consideradas éticas são aquelas cuja conduta é socialmente valorizada e cujas políticas se reconhecem sintonizadas com a moral vigente, subordinando as suas atividades e estratégias a uma reflexão ética prévia e agindo posteriormente de forma socialmente responsável.

Almeida (2007) continua citando Bowan (1953), que em seu livro considera que as empresas, adquiriram uma influência crescente na estruturação e desenvolvimento das sociedades, esse aumento de poder deve ser acompanhado de um aumento da responsabilidade, constituindo portanto a RSE uma obrigação dos empresários de adotarem políticas e práticas adequadas aos objetivos e valores da sociedade. Com isso o autor diz que o fato de uma instituição possuir poder, seja ele econômico ou de influência, mesmo que indiretamente, isso a leva a ter atitudes socialmente responsáveis, seria como uma obrigação. Empresas de grande porte, portanto, já avaliam essas práticas com mais cuidado de modo a inseri-las cada vez mais nos planos estratégicos das empresas. Umas são mais atuantes, outras menos, mas a preocupação existe.

No contexto empresarial, a designação responsabilidade social visa destacar o papel central que as empresas representam enquanto organizações humanas, na manutenção e desenvolvimento do bem-estar social. $\mathrm{O}$ conjunto de responsabilidades sociais de uma empresa engloba as ações e políticas de alcance alargado que visam contribuir para o equilíbrio social da comunidade envolvente, situando-se, no entanto, além das exigências especificas da finalidade que justifica a existência da própria organização (ALMEIDA 2007 p.114). 
Continuando, Aith e Guandalini (2006) escreveram uma reportagem para a revista Veja sobre responsabilidade social empresarial, com alguns dados interessantes. Entre os dados eles fizeram um quadro sobre as regras da nova filantropia, baseados nas regras da prática usadas por Bill Gates, que comanda a Bill and Melinda Gates Foundation uma das maiores fundações filantrópicas do mundo. Como se sabe, Bill Gates foi o fundador da Microsoft, gigante do ramo de computadores e softwares, e é um dos maiores exemplos de empresários praticantes da responsabilidade social no mundo:

\begin{tabular}{|c|c|}
\hline \multicolumn{2}{|c|}{$\begin{array}{c}\text { Bill Gates lidera uma geração de jovens milionários que buscam a máxima eficiência e } \\
\text { elevados retornos para investimentos sociais. Suas ações filantrópicas são guiadas pelos } \\
\text { seguintes critérios empresariais: }\end{array}$} \\
$\begin{array}{c}\text { AUTO-SUFICIÊNCIA: Projetos sociais não devem ser } \\
\text { ralos de dinheiro. Sempre que possível, devem criar } \\
\text { suas próprias fontes de renda e se tornar auto- } \\
\text { suficientes financeiramente. Ex.: programas de } \\
\text { microcrédito que rendem juros. }\end{array}$ & $\begin{array}{c}\text { Foco: Não se doa dinheiro } \\
\text { com cuidado, de acordo com o retorno } \\
\text { econômico ou social que podem gerar. As } \\
\text { fundações trabalham com objetivos claros, } \\
\text { como a descoberta da vacina contra a aids } \\
\text { ou a malária. }\end{array}$ \\
\hline $\begin{array}{c}\text { EFICIÊNCIA: Há metas para a obtenção de } \\
\text { resultados efetivos e controles para impedir um } \\
\text { inchaço da burocracia filantrópica. Fundações não } \\
\text { devem gastar mais que 20\% do que emprestam }\end{array}$ & $\begin{array}{c}\text { TRANSPARÊNCIA: As ações filantrópicas } \\
\text { e sua administração financeira passam por } \\
\text { auditoria e apresentam relatórios anuais de } \\
\text { suas atividades e resultados. }\end{array}$ \\
\hline
\end{tabular}

Fonte: Reprodução total do quadro de Aith e Guandalini para revista Veja - 5 de julho de 2006

Figura 7: As regras da nova filantropia, por Bill Gates.

Na mesma reportagem Aith e Guandalini (2006) citam o termo filantropia na era da eficiência, no século XXI. Eles argumentam que a revolução tecnológica e a popularização do capitalismo permitiram um maior acúmulo de grandes fortunas por um número cada vez maior de pessoas, e pessoas cada vez mais jovens:

Só nos Estados Unidos, o terceiro setor movimenta 260 bilhões de dólares anualmente, empregando cerca de 12 milhões de trabalhadores. Alguns dos filantropos da era da eficiência exigem retorno financeiro de seus investimentos sociais. É o caso de Pierre Omidyar, fundador do site de leilões eBay, que tem programas sociais de microcrédito. (REVISTA VEJA 2006 - p. 65).

Continuando, interessante citar a reportagem que também traz três entraves a filantropia no Brasil que são: 


\section{ENTRAVES À FILANTROPIA NO BRASIL}

Legislacão: Nos EUA, onde doações individuais à filantropia geram créditos tributários, 89\% das famílias dão dinheiro a programas sociais ou religiosos. Do total de recursos doados por lá, 75\% vêm de cidadãos comuns. Pessoas físicas praticamente não gozam desse benefício fiscal no Brasil - apenas empresas e fundações.

Burocracia: Restrições legais quase intransponíveis dificultam a doação individual de dinheiro e equipamentos para universidades públicas. $O$ brasileiro que quiser doar livros para uma universidade, por exemplo, é obrigado a pagar impostos.

Corrupcão e caixa 2: Escândalos sucessivos com empresas de filantropia jogaram uma nuvem de suspeição sobre entidades do setor.

Fonte: Reprodução total do quadro de Aith e Guandalini para revista Veja - 5 de julho de 2006, p. 68. Figura 8: Entraves à Filantropia no Brasil.

Esses três fatores citados na figura 8 influenciam as práticas de responsabilidade sócio-ambiental das empresas no Brasil. Os empresários muitas vezes levam em consideração esses fatores antes de implementarem alguma atividade do ramo em suas empresas ou de fazerem doações. Infelizmente muitas pessoas ainda não tiveram consciência da real importância dessas práticas exercidas pelas empresas e não colaboram para que elas sejam mais atuantes, e assim, possam colaborar melhor na complementação de políticas sociais. A corrupção e a burocracia por exemplo, são entraves muito conhecidos aqui no Brasil, infelizmente.

\subsection{Influência da Sociedade Civil e do Setor Público nas práticas de Responsabilidade social}

Soares e Carvalho (2007) escreveram sobre o conceito de sociedade civil. O conceito nasce nos séculos XVIII e XIX como oposição (ao mercado e/ou ao Estado). [...] Uma apreensão ampla do conceito de sociedade civil se refere a tudo o que não é Estado e nem diz respeito à vida privada dos cidadãos.

Jean Cohen afirma que ela é "uma esfera de interação social diferenciada da economia e do Estado, composta de três parâmetros analiticamente distintos: pluralidade, publicidade e privacidade, e nasceu de processos de constituição e mobilização independentes (p. 27)

Soares e Carvalho (2007) continuam que nas ultimas três décadas a idéia de sociedade civil tem servido para designar desde associações voluntárias, até redes mundiais, ONGs, 
grupos dos direitos humanos, entre outras coisas. [...] Alberto Melucci, citam as autoras, enfatizou o aspecto dinâmico, criativo e contestador da sociedade civil.

Pinheiro (200?) também escreveu sobre o conceito de sociedade civil. Ele começou seu trabalho com a seguinte frase: Sociedade civil, um dos conceitos mais citados e, ao mesmo tempo, mais obscuros da teoria política contemporânea. De fato, o conceito de sociedade civil abrange vários significados, possui diversas variáveis de acordo com teóricos, autores etc.

Pinheiro (200?) continua que a diversidade de significados que carrega o termo sociedade civil é notória. Esse conceito tem uma longa e tortuosa história no campo das idéias políticas. Gomez (2003) apud Pinheiro (200?) cita que a sociedade civil tem sido vista como “ uma esfera não-estatal, antiestatal, pós-estatal e até supra-estatal”.

Pinheiro (200?) também cita Rousseau apud Colas (2002): o primeiro homem que, tendo cercado um pedaço de terra, (...) dizendo isto é meu, e encontrando pessoas simples o bastante para acreditar nele, foi o fundador real da sociedade civil. [...] Hegel, identificava a sociedade civil como um espaço historicamente concreto de interação social entre indivíduos.

Quatro teorias acerca do termo sociedade civil são citadas por Pinheiro (200?) e são resumidamente descritas a seguir:

- Neotocquevillianos: para eles a sociedade civil é um local habitado por organizações de associação livre, da qual o cidadão possa participar de acordo com seus interesses privados, vinculando-se com outros por meio de ajuda mútua.

- Matriz neoliberal: o bem-estar segundo esta matriz pertence ao âmbito privado, ou seja, as famílias, a comunidade, as instituições religiosas e filantrópicas. Existe uma estratégia substitutiva, de descentralização e privatização de serviços públicos, desobrigando assim os governos da responsabilidade pela implementação de programas sociais.

A sociedade civil, segundo esta matriz seria então, o vasto setor nãogovernamental, formado por associações comunitárias, movimentos sociais, ONGs, entidades beneficentes, associações profissionais, igrejas e fundações de empresas. (GARRISON 2000 apud PINHEIRO 200? p. 86)

- Matriz Habermasiana: para esta matriz a sociedade civil seria, o mundo da vida conforme este é expresso nas instituições. Incluindo todas as instituições e formas associacionais que requerem interação comunicativa para sua reprodução e que confiam...

\footnotetext{
...primariamente em processos de integração social para ação coordenada dentro de suas fronteiras. [...] Percebe-se que o que proporciona as relações na sociedade civil é a comunicação, e a sociedade civil é autônoma quando suas atividades são governadas por normas que são tiradas do mundo da vida e reproduzidas e reformuladas através da comunicação (PINHEIRO 200? p. 89)
} 
- Matriz Gramsciana: para Gramsci, sociedade civil é “o conjunto de organismos designados vulgarmente como privados", e é formada pelas organizações responsáveis tanto pela elaboração quanto pela difusão das ideologias, compreendendo assim...

... o sistema escolar, as igrejas, os sindicatos, os partidos políticos, as organizações profissionais, a organização material da cultura (jornais, revistas, meios de comunicação de massa), etc. (PINHEIRO 200? p. 93).

Nogueira (2009) classificou o setor público. Para ele setor público designa o conjunto de órgãos, entidades e empresas estatais pertencentes a uma determinada esfera do Governo (municipal, estadual ou federal). Poderia segundo o autor ser sinônimo de administração pública e opõe- se ao setor privado. [...] De um modo geral, segundo o autor, a expressão refere-se à participação dos órgãos, entidades e empresas estatais na economia. Esse conceito é o válido para este trabalho.

Nogueira (2009) continua argumentando que o setor público existe porque o sistema de mercado tem falhas. Assim o governo emerge como elemento capaz de intervir na alocação de recursos, atuando paralelamente ao setor privado. O governo atua dessa forma também na medida em que é responsável pela manutenção e elaboração de leis que regem o país. Quando ele estipula, por exemplo, regras, medidas, etc., para que sejam usufruídos ou cumpridos pela sociedade, e por todos os elementos que dela fazem parte, ele está exercendo um poder de controle.

Continuando descrevendo as praticas de responsabilidade social, Trevisan (2002) citou que o Instituto Ethos, criado em julho de 1998, já contava em 2002 com mais de 430 empresas associadas, que correspondiam por cerca de $20 \%$ do PIB nacional na época da pesquisa. Ele também se referiu ao já citado termo Balanço Social que é um demonstrativo que permite a visualização das atividades desenvolvidas pela empresa, desde a proteção do meio ambiente como a geração de empregos e permite identificar aquela empresa que agrega mais valor à sociedade. Como já mencionado, atualmente - ano de 2010, segundo o site do Instituto Ethos, 1368 empresas estão associadas a ele, ou seja, o número mais que triplicou em um pouco menos de uma década. Só no Distrito Federal, existem 21 empresas associadas, entre elas: APEX - Brasil, Bancorbrás, Cooperforte, Caixa, SERPRO, Laboratório Sabin, Vivo Centro Oeste/ Norte, Corpore BR, entre outras. Os governos tem interesse no trabalho social destas empresas, pois elas contribuem significantemente no desenvolvimento da comunidade e das pessoas a elas relacionadas. Segundo o Instituto Ethos, o faturamento das empresas a ele associadas correspondem a cerca de 35\% do PIB brasileiro, e empregam em torno de dois milhões de pessoas. (INSTITUTO ETHOS). 
Todas essas empresas listadas pelo Instituto Ethos, contribuem para a movimentação da economia nacional, visto que movimentam economicamente uma quantia equivalente a boa parte do PIB nacional. Quanto maior o lucro das empresas mais elas poderiam colaborar com tais projetos, gerar empregos e conseqüentemente renda.

Baggio (1999) apud Trevisan (2002) também cita que a RSE - Responsabilidade Social Empresarial - reflete uma mudança progressiva nos papéis das companhias, onde se espera delas retorno à comunidade face ao lucro obtido com os negócios, tanto as empresas ou a sociedade civil assumem cada vez maiores responsabilidades perante a comunidade.

No Brasil, o projeto de Lei $\mathrm{n}^{\circ}$ 3116/97 das então deputadas Marta Suplicy, Maria da Conceição Tavares e Sandra Starling, que previa que empresas que tivessem mais de 100 empregados seriam obrigadas a publicar um Balanço Social e caso não publicassem estariam sujeitas a multas e ficariam impedidas de participar de licitações, etc., ainda não virou lei. Com isso o Instituto Brasileiro de Analises Sociais e Econômicas (IBASE), em parceria com representantes de empresas públicas e privadas desenvolveu um modelo simples de Balanço Social para organizar e incentivar esse tipo de ação no Brasil (TREVISAN 2002).

Romaniello e Amâncio (2005) escreveram que aspectos como a desigualdade social, aumento da complexidade dos negócios, etc. impõe às empresas uma nova maneira de trabalhar no mercado que depende da adoção de procedimentos de gestão que lhes garantam a condução dos negócios de maneira que elas se tornem também responsáveis pelo desenvolvimento econômico, social e ambiental.

Daft (1999) apud Romaniello e Amâncio (2005) citou que a responsabilidade social é a obrigação da administração de tomar decisões e ações que irão contribuir para o bem-estar e os interesses da sociedade e da organização.

Ferrell et al. (2001) apud Romaniello e Amâncio (2005) também afirmaram que "responsabilidade social no mundo dos negócios consiste na obrigação da empresa em maximizar seu impacto positivo sobre os stakeholders que são entre outros: os clientes, proprietários, comunidade, governo, etc.).

Já Melo e Neto \& Fróes (2001) apud Romaniello e Amâncio (2005) escreveram que responsabilidade social de uma empresa consiste na sua "decisão de participar mais diretamente das ações comunitárias na região em que está presente e minorar possíveis danos ambientais decorrentes do tipo de atividade que exerce"

Anna Peliano, socióloga do IPEA, também foi citada por Romaniello e Amâncio (2005). Ela considera que as pessoas deveriam consumir bens de empresas socialmente 
responsáveis, o que seria o consumo solidário. A sociedade deve pressionar e compreender que os problemas sociais brasileiros não podem ser resolvidos apenas pela ação de governos.

Ribeiro et al. (2001) cita Mário Gordilho, à época, Presidente da Conder - órgão do Estado da Bahia, que disse que o relacionamento empresa-estado tende a aumentar, pois é muito bom para a comunidade.

O Estado, a iniciativa privada e os cidadãos reunidos em beneficio de causas sociais, é o principio básico do agir com responsabilidade social (p.9).

A empresa quando participa mais diretamente da comunidade na qual está inserida pratica a responsabilidade social, minimizando possíveis danos ambientais do tipo de atividade que exerce (MELO NETO apud RIBEIRO et al. 2001).

Ribeiro et al. continuam que as empresas têm se preocupado com os problemas que a sociedade na qual estão inseridas enfrentam, elas passam a compreender a importância de se responsabilizarem por áreas nas quais o Estado não tem conseguido suprir eficientemente as necessidades da população.

Com todas essas afirmações, é fácil concluir que o Estado e o Governo tem interesse na prática da responsabilidade social. Para isso ele exerce papel importante, regulamentando e incentivando essas atividades.

Sá (2003) escreveu que ao exercerem sua responsabilidade social, as empresas estão adquirindo uma vantagem comparativa sem precedentes em relação às suas concorrentes e o grande beneficio é que esta vantagem é multiplicada, pois se converte em ganhos para a sociedade.

As empresas ganham descontos fiscais; as instituições beneficiadas conseguem oferecer um futuro melhor para seus associados e a sociedade como um todo ganha, pois dar educação aos menos favorecidos pode significar qualificar pessoas para o mercado de trabalho, evitando que o caminho destes seja as ruas, drogas e o crime (p.1).

Mânica (2005) descreve a relação do Terceiro Setor com o Estado. Desde o final da década de 20 do século passado, as entidades prestadoras de serviços de interesse recebiam auxilio do Estado por meio de pedidos endereçados ao Presidente da Republica.

Utilizava-se para tanto recursos advindos da chamada contribuição de caridade, cobrada sobre a importação de bebidas alcoólicas. [...] Em 1959, foi oficializada a possibilidade de isenção fiscal da contribuição à previdência social, sendo que a lei instituidora do beneficio determinou que teriam acesso à isenção apenas as entidades dotadas do certificado de fins filantrópicos. Surgiu nesse momento mais uma atribuição ao CNSS - Conselho Nacional do Serviço Social: fornecer o certificado de fins filantrópicos (p.12 e p.14).

Mânica (2005) também cita duas leis que surgiram na década de 1990, que tratam de interesses do Terceiro Setor e da prática da responsabilidade social. O Estado com o aumento 
do número de OSCIPs e de outras entidades de Terceiro Setor buscou com essas leis legitimar tais práticas.

A primeira lei é $\mathrm{n}^{\circ} 9.637 / 98$ que: Dispõe sobre a qualificação de entidades como organizações sociais, a criação do Programa Nacional de Publicização, a extinção dos órgãos e entidades que menciona e a absorção de suas atividades por organizações sociais, $e$ dá outras providências. (SITE PRESIDÊNCIA DA REPÚBLICA)

A segunda lei é a n 9.790/99 que: Dispõe sobre a qualificação de pessoas jurídicas de direito privado, sem fins lucrativos, como Organizações da Sociedade Civil de Interesse Público, institui e disciplina o Termo de Parceria, e dá outras providências. (SITE PRESIDÊNCIA DA REPÚBLICA).

Também é importante citar como o Estado influencia o Terceiro Setor e as práticas da responsabilidade social através de regras de tributação.

Cruz (2006) escreveu que ser uma ONG geralmente garante à organização o direito à isenção de Imposto de Renda. Contudo, é necessário cuidado. Se quiser a isenção deste imposto, a entidade segundo ele, não pode remunerar seus dirigentes. O decreto 3.000/99, Art. 174 e a Lei 9.532/97 artigo 15 tratam da isenção de imposto de renda, ambos possuem a mesma matéria:

Estão isentas do imposto as instituições de caráter filantrópico, recreativo, cultural e científico e as associações civis que prestem os serviços para os quais houverem sido instituídas e os coloquem à disposição do grupo de pessoas a que se destinam, sem fins lucrativos. (SITE JUSBRASIL).

Já Entidade sem fins lucrativos segundo Cruz (2006) é aquela:

“... que não apresente superávit em suas contas ou, caso o apresente em determinado exercício, destine referido resultado, integralmente, à manutenção $e$ ao desenvolvimento dos seus objetivos sociais". (Redação dada pela Lei $n^{\circ} 9.718$, de 1998) (SITE RECEITA FEDERAL).

As entidades sem fins lucrativos, que englobam as do já citado Terceiro Setor, como as OSCIPS e/ou ONGs, Fundações, Associações, Cooperativas, entre outras complementam as atividades do Estado, à medida que prestam serviços sociais que o Estado, a principio deveria suprir em sua integralidade (CRUZ 2006). A Lei 9.532/97 em seu artigo 12 também diz que:

Para efeito do disposto no art. 150, inciso VI, alínea "c", da Constituição, considera-se imune a instituição de educação ou de assistência social que preste os serviços para os quais houver sido instituída e os coloque à disposição da população em geral, em caráter complementar às atividades do Estado, sem fins lucrativos. (SITE RECEITA FEDERAL).

Oliveira e Schwertner (2007) escreveram sobre os incentivos governamentais nas praticas de responsabilidade social empresarial. Citam os autores: 
Infelizmente, no Brasil, até por uma questão de bases históricas, os estímulos legais, voltados às ações de práticas sociais sofreram uma tendência a beneficiar entidades sem fins lucrativos ou também chamadas filantrópicas, onde os incentivos à filantropia privada ainda permanecem um tanto quanto tímidos, sendo um dos importantes a dedutibilidade do imposto de renda, como por exemplo, ocorrem nos casos de estimulo às atividades de caráter cultural, audiovisual, artístico, desportivo, de ensino e pesquisa, bem como de auxílios as crianças e adolescentes (p.7).

Oliveira e Schwertner (2007) continuam que o empresariado pode obter benefícios fiscais, em contrapartida concedida pelo Estado, pela prática de ações de cunho social. Seria uma recompensa às empresas que investem no âmbito social, tornando essas atividades mais atrativas. Entre os Programas, Fundos, Ações e Leis, que o empresariado pode usar para tais práticas estão: o Fundo dos Direitos da Criança e do Adolescente - FUNCRIANÇA ou FIA; Programa Universidade para todos - PROUNI, Lei Rouanet de Incentivo à Cultura; Lei do Audiovisual; Doações às OSCIPs e Doações às Entidades sem Fins Lucrativos.

As principais leis de incentivos fiscais são descritas por Machado (2005):

- Lei Rouanet: Lei Federal de Incentivo à Cultura. Prioriza o produto cultural brasileiro. O incentivo está limitado a $4 \%$ do imposto devido pelas pessoas jurídicas tributadas com base no lucro real em cada ano calendário, $[\ldots]$ do ponto de vista financeiro e fiscal os benefícios são os mais atraentes das leis de incentivos.

- Lei do Audiovisual: Lei $n^{\circ} 8.685 / 1993$, autoriza que sejam abatidos do imposto de renda das pessoas jurídicas e físicas os valores utilizados na compra de certificados de investimentos das obras cinematográficas de produção independente, até o limite de $3 \%$ do imposto de renda das pessoas jurídicas (MACHADO 2005)

- Fundo dos Direitos da Criança e do Adolescente: Estabelece que os contribuintes do imposto de renda de pessoas jurídicas e físicas podem deduzir do imposto devido às doações efetivadas junto aos Fundos em âmbito Federal, Estadual e Municipal [...].

As pessoas jurídicas podem abater doações efetuadas ao FIA dentro do ano calendário aos Fundos até o limite de $1 \%$ do Imposto de Renda devido diretamente no imposto a pagar e não será dedutível como despesa operacional. É considerado o mais atrativo e importante incentivo voltado para a área social no Brasil. (p. 20-24)

- Doações para Entidade sem Fins Lucrativos e OSCIPs: As pessoas jurídicas, podem fazer doações na forma da lei $n^{\circ}$ 9.249/ 1995, para entidades sem fins lucrativos ou às qualificadas como OSCIPs...

...que prestem serviços gratuitos em beneficio de empregados da pessoas jurídica doadora e respectivos dependentes, ou beneficio da comunidade onde atuam. A lei estabelece no seu artigo 13 que a dedução integral das doações efetuadas pela pessoa jurídica podem ser realizadas até o limite de $2 \%$ do lucro operacional bruto. (p.24-25) 
- Doações a Entidades de Ensino a Pesquisa: É permitida a dedução da doação na base de cálculo do Imposto de Renda até o limite de 1,5\% do lucro operacional, antes da sua dedução do Imposto de Renda.

...e a dedução da doação às entidades civis que prestem serviços gratuitos. $\mathrm{O}$ retorno para a pessoa jurídica que utiliza esse tipo de incentivo é da ordem de $25 \%$ do valor doado (p.25).

Schwertner e Oliveira (2007) também descreveram o PROUNI: o Programa Universidade para Todos é um programa do Governo Federal que visa promover o acesso ao ensino superior, mediante a concessão de bolsas de estudo por Instituição de Ensino Superior, com ou sem fins lucrativos...

... a Instituição que aderir ao PROUNI, terá a isenção de alguns impostos e contribuições, no período de vigência do termo de adesão ao programa ( p. 8)

Peliano (2001) descreveu porque em meados dos anos 1990 as práticas de responsabilidade social cresceram. Entre os fatores ela cita: abertura econômica, privatização de empresas estatais, crise política e econômica,...

... fortalecimento da sociedade civil - como exemplo a Ação da Cidadania, maior
envolvimento de ONGs; busca de melhoria na qualidade dos processos de gestão
das empresas nacionais, redução de atuação do Estado e crescente envolvimento
das empresas privadas em ações sociais (PELIANO 2001 p. 19).

Para se analisar o papel do Estado e do Setor Público no fomento do crescimento das práticas de responsabilidade social na década de 1990, segue um breve histórico do que ocorreu nesses anos. Giambiagi (2008) descreve o panorama econômico do final dos anos 1990, anos em que leis de incentivo às práticas de responsabilidade social foram aprovadas como as leis $n^{\circ} 9.637 / 98$ e $n^{\circ}$ 9.790/99. Em 1998 continuando com as privatizações, marcantes no governo Fernando Henrique Cardoso, foi privatizada a Telebrás. Contudo havia problemas pendentes: o fiscal - com uma enorme divida pública e o externo com um déficit em conta corrente que ameaçava atingir 5\% do PIB. [...] Reformas estruturais foram necessárias para se resolver o problema fiscal brasileiro. Em 1998 foi aprovada a Emenda Constitucional da previdência social e em 1999 o Fator previdenciário. Em 1999 começaram os debates acerca da Lei de Responsabilidade Fiscal, que finalmente foi aprovada no ano 2000 (GIAMBIAGI 2008).

Após oito anos de um Governo de características neoliberais, a preocupação com o social não foi, naturalmente, totalmente esquecida, mas certamente não foi a prioridade da era Fernando Henrique Cardoso, o que de certo modo ajudou no aumento das práticas de responsabilidade social pelas empresas e pela sociedade civil no geral. Explicando melhor o contexto da reforma de estado, Bezerra et. al. (2009) escreveu que o Estado retirou seu foco 
da sociedade, transferindo-o para si mesmo, no intuito de garantir o funcionamento de sua estrutura por meio de seus mecanismos de controle.

Com a ampliação de serviços disponibilizados pelo Estado, que antes eram apenas
manter a ordem e administrar a justiça, garantir os contratos e a propriedade, a
estrutura burocrática torna-se ineficiente, auto-referente e incapaz de voltar-se para o
serviço aos cidadãos vistos como clientes. (Bresser Pereira 2008 apud Bezerra et. al.
2009). Nesse contexto surge, uma nova concepção de administração pública, o
modelo gerencial, que surgiu na era Thatcher, Grã Bretanha, em 1979 [...] Nos EUA
mais tarde, na era Reagan, este modelo é aplicado com o ideário de um crescimento a
partir da iniciativa individual (BEZERRA ET. AL. 2009 p. 3).

Bezerra et. al. (2009) continuam que no modelo gerencialista, tem-se o cidadão no serviço público apenas como usuário de um serviço ou de um bem. Esta percepção deixa transparecer a idéia de um Estado que não enfoca seus esforços na satisfação das necessidades sociais. [...] Defendido por Luiz Carlos Bresser Pereira, esse modelo gerencialista foi implementado no Brasil em 1995, graças ao Plano Diretor da Reforma do Aparelho do Estado.

Seu objetivo central é a transformação de autarquias e fundações em agências autônomas com ampla liberdade para administrar os recursos humanos, materiais e financeiros colocados à disposição, desde que atinjam os objetivos qualitativos e quantitativos (indicadores de desempenho) previamente acordados, e transfiram para o setor público não estatal estes serviços, através de um programa de publicização, transformando as atuais fundações públicas em organizações sociais (BRESSER PEREIRA 2007,2008 apud BEZERRA et. al. 2009 p. 5)

Bresser Pereira, em entrevista concedida à revista Getúlio em 2010 falou sobre o surgimento das Organizações Sociais e das OSCIPs no Brasil. Ele se diz o criador das Organizações Sociais. Segundo ele, Ruth Cardoso, que cuidava da parte social do governo na época, teve interesse em estabelecer um marco jurídico para o Terceiro Setor. Bresser Pereira se refere a essas entidades como públicas não estatais.

"Ruth Cardoso viu o modelos das organizaçẽes sociais, conversou comigo e
resolveu criar um marco jurídico usando um pouco as idéias das OS. [...] Pela lei,
uma OSCIP é uma entidade sem fins lucrativos que tem determinadas vantagens do
ponto de vista fiscal caso cumpra algumas exigências".

Garcia (200?) também escreveu sobre o desenvolvimento da responsabilidade social no Brasil. Na década de 1990, o país passou a ser alvo das já citadas políticas "neoliberais", as teorias do Estado Mínimo, fomentaram propostas que valorizavam o papel da sociedade civil na resolução de problemas sociais, sendo essa fase para muitos autores, a origem do termo "terceiro setor" no país.

Para Garcia (200?) "sociedade civil” significa entre outras coisas, lidar com o conjunto de setores organizados da sociedade, considerando que tais organizações são voluntárias e autônomas, em relação ao Estado e ao mercado. 
Garcia (200?) continua que tem aumentado no Brasil os investimentos privados com vistas no bem público. Ele também cita Ruth Cardoso, que dizia que o terceiro setor na sociedade, busca enfatizar o caráter autônomo e inédito de algo novo que, está mudando a sociedade e que se difere "por não ser nem governo nem empresa, por não querer submeterse nem á lógica do mercado nem à lógica governamental”.

Rubem Cesar Fernandes apud Garcia (200?) acredita que a grande força do terceiro setor estaria ancorada nos valores morais da solidariedade e voluntariedade, sendo os principais componentes: movimentos sociais e associações civis, filantropia empresarial, ONGs, etc. Nesse mesmo trabalho Garcia (p.14) cita o fundador do Instituto Ethos, Oded Grajew, que disse certa vez:

A questão da responsabilidade social, que se une à possibilidade do sucesso da
empresa, dá oportunidade a cada um de dar um outro sentido à vida individual e
coletiva. A empresa pode afirmar com segurança que faz algo para que a vida
pessoal e coletiva tenha mais sentido, porque ela está provocando mudanças
positivas na sociedade.

Continuando com Peliano (2001), ela escreveu que o Estado possui dificuldades para responder às crescentes demandas por benefícios sociais, com isso ganharam força as organizações não governamentais e empresas privadas que desempenham atividades sociais, como agentes sociais da era globalizada, e são também responsáveis por propiciar à sociedade tudo aquilo que o Estado já teria demonstrado não ter condições de fazer de forma eficiente.

A gravidade das condiçães sociais, associada à crise econômica e a instabilidade
política do inicio da década de 1990 , reforçou a mobilizaçãa da sociedade e seu
envolvimento na causa social. Ė dessa época a criação do "Movimento pela Ética
na Política", que se notabilizou na luta pelo impeachment do ex-presidente Collor,
desdobrando-se na campanha da "Ação da Cidadania contra a Fome, a Miséria e
pela Vida". A "Ação da Cidadania" evocou o sentimento de solidariedade nacional
em favor dos excluídos e promoveu inúmeras campanhas de distribuição de
alimentos em todo o pais, impulsionadas pelo sentimento de indignação contra a
fome, a miséria e a exclusão. No centro desse movimento destacou-se a
participação de Herbert de Souza. (PELIANO 2001 p. 20)

Peliano (2001) escreveu também que as empresas privadas ajudam fazendo doações isoladas a pessoas físicas ou entidades assistenciais; realização direta de projetos estruturados, apoio a ações governamentais, etc. As empresas credenciam-se como atores importantes para a promoção do desenvolvimento social do país.

É importante salientar o papel que os dirigentes das organizações desempenham nas práticas de responsabilidade social das empresas. Normalmente esses diretores, presidentes, conselheiros, etc. inserem práticas sociais nas suas organizações movidos por um ideal muitas vezes fomentado por experiências pessoais. O fato deles serem ou terem sido atuantes em entidades de terceiro setor ou em movimentos sociais contribui muito para o envolvimento 
das empresas, que eles dirigem, na realização de ações sociais. Nesse aspecto, as próprias organizações de terceiro setor, a família e os valores, religião, ou experiências de vida influenciam nas decisões das lideranças empresariais, e colaboram para que atividades de responsabilidade social sejam tão importantes para algumas empresas. (PELIANO 2001)

O setor público, através do Estado e do Governo é percebido por muitos como inoperante ou mal operante em relação a algumas políticas sociais. $\mathrm{O}$ atendimento social embora não solucione em sua totalidade os problemas sociais, pode melhorar e muito a qualidade de vida das pessoas. Isso contribui para que as empresas exerçam determinadas atividades e prestem diversos atendimentos na área de assistência social, saúde, educação entre outros, complementando de alguma forma políticas sociais governamentais, como exemplos (PELIANO 2001):

- Na assistência social:

- Ajuda financeira à pessoa física carente;

- Assistência social e médica a entidades assistenciais;

- Doações financeiras para entidades;

- Recolocação profissional de idosos e jovens;

- Hortas comunitárias;

- Práticas esportivas na comunidade;

- Pagamento de contas de entidades assistenciais;

- etc.

- Ações desenvolvidas na saúde:

- Palestras sobre higiene pessoal;

- Pagamento de consultas médicas especializadas;

- Curso preparação para gestante com doação de enxoval;

- Convênios com universidades para financiar pesquisadores na área de saúde;

- Doação de medicamentos;

- etc.

- Ações desenvolvidas em educação e alfabetização:

- Adoção de escola pública;

- Mobilização para volta de crianças de baixa renda à escola;

- Doações livros didáticos;

- Capacitação e formação de professores;

- Formação de bibliotecas nas escolas;

- Educação em informática; 
- Doação de escolas para comunidades ( construção e infra-estrutura);

- etc. (PELIANO 2001).

Observa-se que as empresas complementam atividades sociais, que a principio são desenvolvidas ou deveriam ser pelo Estado. As empresas com suas práticas sociais colaboram com o Estado em algumas regiões, cidades ou comunidades, financiando ou exercendo atividades relacionadas à saúde, educação e assistência social, áreas onde de fato o governo precisa mais dessa complementação, porque são serviços que demandam mais. Para explicitar Rezende (2002) comprova este fato escrevendo que saúde, educação e transporte, nessa ordem, destacam-se como as funções que apresentam um grau elevado de gastos em âmbito governamental. Atrás de Previdência social e encargos especiais, saúde, energia e educação englobam as maiores despesas do Orçamento Geral da União. Com isso, embora o governo já reserve boa parcela de seus gastos com saúde e educação, observa-se que essas duas áreas ainda enfrentam muitos problemas e que a ajuda empresarial, através de doações, ou desenvolvimento de projetos ou programas é de grande valor. Na medida em que o governo não consegue suprir adequadamente a população, ele (o governo) acaba influenciando de algum modo as empresas a optarem mais por essas duas áreas em seus projetos de responsabilidade social. Peliano (2001) inclusive escreveu que o potencial de atendimento prestado pelas empresas é muito mais o de complementar do que de substituir o Estado.

As empresas tem aplicado grandes valores em atividades de cunho social. Continuando com a pesquisa de Peliano (2001), ela analisou vinte e uma empresas que investiram as seguintes quantias:

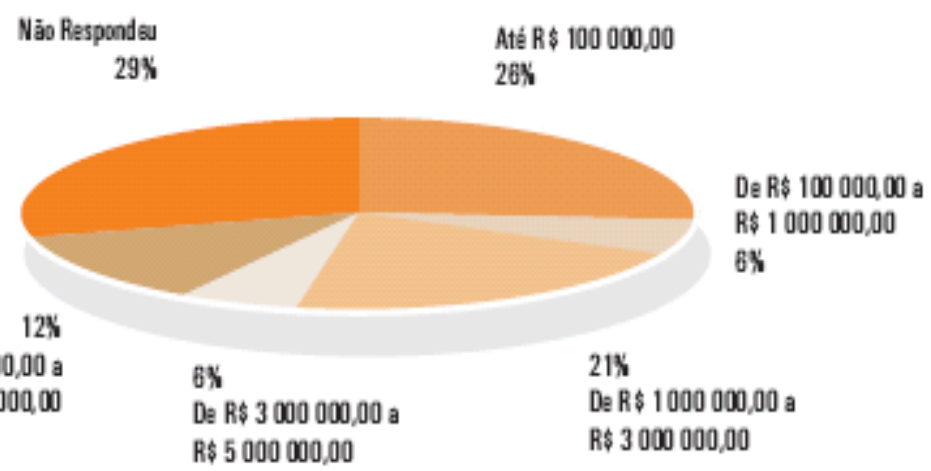

Fonte: Pesquisa Ação Social das Empresas - IPEA/DICOD (2001) apud Peliano (2001). Social.

Figura 9: Distribuição das Empresas por montante de recursos aplicados na Ação

Dessas empresas pesquisadas por Peliano (2001) $70 \%$ atuam em conjunto com entidades ou órgãos governamentais, ainda que nem sempre essas parcerias sejam formalizadas: 
São diversos os caminhos trilhados para uma participação conjunta. [...] Entre as formas encontradas para se trabalhar nessa parceria, destacam-se, nesta ordem: cessão de recursos humanos e materiais para programas governamentais; realização de campanhas de mídia relacionadas a temas sociais; apoio financeiro a programas governamentais; participação em comissões, conselhos ou grupos de trabalho de que participam representantes governamentais (p.92).

Como exemplo dessas parcerias Peliano (2001) desenvolveu o seguinte quadro:

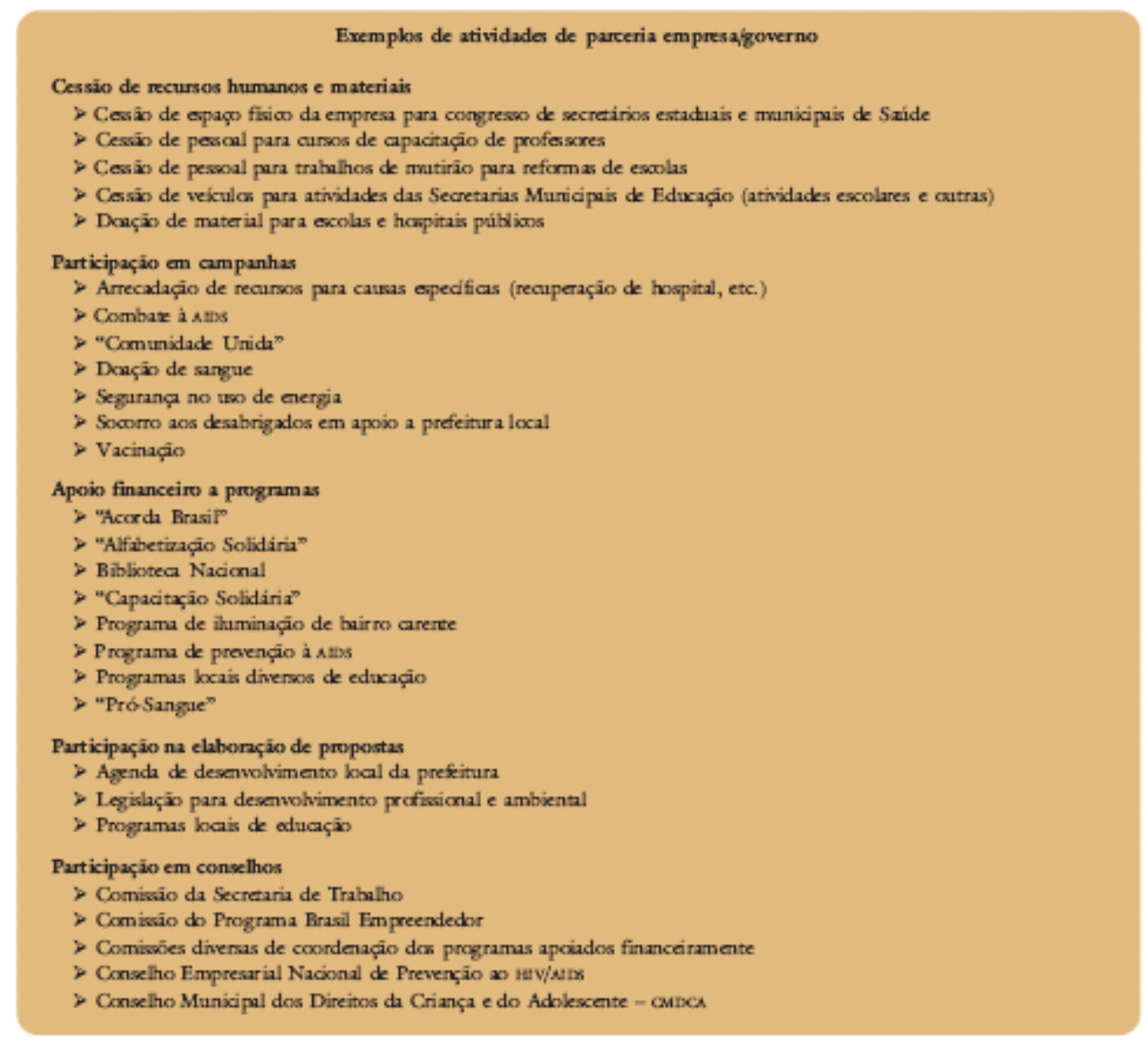

Fonte: Peliano (2001)

Figura 10: Exemplos de atividades de parceria empresa/governo.

Em relação ao papel da sociedade civil, Machado (2006) cita as ações dos stakeholders. As empresas possuem responsabilidades sociais para com um amplo conjunto de agentes. A figura 11 apresenta um resumo de ganhos ou minimização de riscos, de acordo com o agente envolvido, a partir de ações de responsabilidade social: 


\begin{tabular}{|c|c|c|}
\hline $\begin{array}{l}\text { Stakeholder } \\
\text { envolvido }\end{array}$ & $\begin{array}{l}\text { Oportunidades } \\
\text { (ganhos de } \\
\text { reputação) }\end{array}$ & Minimização de riscos \\
\hline Comunidade & $\begin{array}{l}\text { Criação de } \\
\text { legitimidade }\end{array}$ & Minimizar risco de má-aceitação/conflitos \\
\hline Mídia & Cobertura favorável & Minimizar risco de cobertura desfavorável \\
\hline Ativistas & $\begin{array}{c}\text { Colaboração/imagem } \\
\text { favorável }\end{array}$ & Minimizar risco de boicote \\
\hline Investidores & Geração de valor & Minimizar risco de fuga de investidores \\
\hline Funcionários & $\begin{array}{c}\text { Aumento do } \\
\text { Comprometimento }\end{array}$ & Minimizar risco de mau comportamento \\
\hline Consumidores & Fidelização & Minimizar risco de má aceitação/desentendimentos/boicotes \\
\hline $\begin{array}{c}\text { Agentes } \\
\text { reguladores }\end{array}$ & Ação legal favorável & Minimizar risco de ação legal desfavorável \\
\hline $\begin{array}{l}\text { Parceiros } \\
\text { Comerciais }\end{array}$ & Colaboração & Minimizar risco de abandono \\
\hline
\end{tabular}

Fonte: Fombrun (2000 - Adaptado) apud Machado (2006) - Reprodução total de Machado (2006).

Figura 11: Efeitos das ações de responsabilidade social de acordo com o stakeholder envolvido. 


\section{METODOS E TÉCNICAS DE PESQUISA}

\subsection{Tipo e descrição geral da pesquisa}

Como em todas as monografias de conclusão de curso de graduação, um dos métodos de pesquisa mais utilizados é a revisão de literatura. A análise de estudos, presentes na literatura e no meio acadêmico que já foram realizados acerca do tema escolhido e uma comparação com a pesquisa realizada, é o método utilizado nesta monografia. A pesquisa realizada foi com três representantes de empresas do Distrito Federal que desenvolvem práticas de responsabilidade social, duas associadas ao Instituto Ethos e uma empresa social OSCIP. Foi uma pesquisa do tipo qualitativa, de coleta de dados e opiniões.

Foi utilizada a pesquisa ação que segundo Roesch (2006) é uma estratégia de pesquisa que permite obter conhecimento de primeira mão sobre a realidade social empírica, e permite ao pesquisador desenvolver os componentes analíticos, conceituais e categóricos de explicação.

Neste trabalho a entrevista em profundidade também foi utilizada, Roesch (2006) continua que seu objetivo primário é entender o significado que os entrevistados atribuem a questões e situações em contextos que não foram estruturados anteriormente a partir das suposições do pesquisador.

No caso deste trabalho as entrevistas se basearam-se na opinião dos entrevistados acerca da responsabilidade social empresarial, incentivos governamentais, papel do Estado e da sociedade nas práticas por elas realizadas.

\subsection{Caracterização}

Das três empresas pesquisadas, uma solicitou anonimato. As duas que não solicitaram são: Cooperforte, que exerce as práticas de responsabilidade social através do Instituto Cooperforte, e a Corpore BR- empresa de gestão de ativos imobiliários, que não possui fundação mas exerce projetos de responsabilidade sócio-ambientais, principalmente referentes à sustentabilidade e cultura. Ambas as empresas possuem sede em Brasília-DF, motivo pelo qual foram selecionadas para a pesquisa. Devido ao pouco tempo disponível para a coleta de dados, o fator localização foi de suma importância, visto que por serem no Distrito Federal, o contato foi facilitado. Também as duas empresas citadas possuem cadastro no 
Instituto Ethos, como empresas do Distrito Federal que são socialmente responsáveis. A terceira empresa que solicitou anonimato é um empreendimento social, ou seja, embora atue em atividades com características comerciais, ela é uma típica organização de terceiro setor, pelo fato de que sua natureza jurídica é de uma associação sem fins lucrativos, ou seja a legislação que ela segue é dessa natureza. È uma empresa do ramo de turismo, que oferece alguns benefícios para seus associados, na sua maioria de baixa renda.

\subsection{Participantes do Estudo}

Foram enviados cinco questionários, mas somente três empresas aceitaram participar da pesquisa. Foram questionários qualitativos, por isso o número reduzido de amostras. As duas empresas analisadas foram: Cooperforte, através do Instituto Cooperforte, e a empresa Corpore BR. A empresa Cooperforte é uma cooperativa de crédito. A Corpore é uma empresa de gestão de ativos imobiliários. A terceira empresa que solicitou anonimato é do ramo de turismo, que tem por finalidade promover a cultura do turismo em populações de baixa renda. É uma empresa social, sem fins lucrativos, que não possui ligação com outra empresa privada.

\subsection{Caracterização do instrumento de pesquisa}

Como já citado, a pesquisa foi qualitativa através de aplicação de entrevistas. Os entrevistados responderam cada pergunta de maneira subjetiva, ou seja, emitiram opiniões ou forneceram informações em cada questão apresentada. Funcionários das empresas, que trabalham com as práticas de responsabilidade social responderam as questões, no caso da Cooperforte e da Corpore BR. Na empresa de turismo, um dos gestores respondeu.

\subsection{Procedimentos de coleta e análise de dados}

A pedido de todas as empresas, a entrevista foi mandada primeiramente por e-mail, para que elas analisassem as perguntas e assim pudessem responder. Como o tempo para a pesquisa não foi longo, os contatos foram, em sua maioria por telefone. Primeiramente, o contato telefônico se deu com aproximadamente oito empresas, destas somente cinco aceitaram analisar o questionário, solicitando que o mesmo fosse enviado por e-mail. Das 
cinco empresas contatadas, que aceitaram colaborar, somente três responderam a entrevista. As empresas enviaram as entrevistas respondidas por e-mail, e posteriormente por telefone outras informações foram fornecidas. Também para análise da literatura e dos dados, pesquisas foram feitas nos sites Scielo, ANPAD, e no site da Revista de administração pública, além de outros. Também importante citar os artigos sobre Orçamento Público e Políticas Públicas, no entendimento da influência governamental no setor social . Materiais fornecidos pelo IPEA, principalmente as pesquisas da socióloga, Anna Maria Peliano, ajudaram na análise dos dados coletados e pesquisados na literatura. Por fim, alguns livros sobre responsabilidade social, marketing, terceiro setor foram também utilizados. 


\section{RESULTADOS E DISCUSSÃO}

O aumento das práticas de responsabilidade social empresarial no Brasil se deu, como já discutido, em meados da década de 1990. Nessa mesma década muitas leis de incentivos fiscais surgiram, além das leis que regulamentavam o terceiro setor. O Estado tentava regularizar as práticas sociais, e também incentivar a responsabilidade social por meio de leis que favorecessem tais práticas. As empresas realmente aproveitam esses benefícios fiscais, oriundos do Setor Público/ Estado? É isso que realmente incentiva as práticas de responsabilidade social pelas mesmas? Interessante também analisar a opinião das empresas acerca do que realmente as motivam a serem socialmente responsáveis. Como a sociedade, aí incluindo todos que fazem parte dela, influenciam as decisões sociais das empresas? O marketing é fator predominante? Isto será discutido adiante.

A primeira empresa a ser analisada é a Cooperforte. Segundo o Sr. Pedro Cardins, que respondeu a entrevista e que é da coordenadoria de projetos do Instituto Cooperforte, a missão do Instituto é promover a inclusão socioeconômica de pessoas em situação de vulnerabilidade social com ênfase na promoção e no desenvolvimento humano.

$\mathrm{Na}$ entrevista, ele citou que a origem do Instituto está ligada a campanhas assistenciais realizadas voluntariamente em Brasília pelos funcionários da Cooperativa de Economia e Crédito Mútuo dos Funcionários de Instituições Financeiras Públicas Federais - Cooperforte, informação também presente no site da empresa.

Sr. Pedro afirmou que o Instituto por ser uma ONG, certificada como OSCIP, é regido de acordo com a lei 9.790 de 30 de junho de 1999 , conforme decreto $\mathrm{n}^{\circ} 3.100$.

O decreto $\mathrm{n}^{\circ} 3.100$ :

Regulamenta a Lei $n^{\circ}$ 9.790, de 23 de março de 1999, que dispõe sobre a qualificação de pessoas jurídicas de direito privado, sem fins lucrativos, como Organizações da Sociedade Civil de Interesse Público, institui e disciplina o Termo de Parceria, e dá outras providências (SITE PRESIDÊNCIA DA REPÚBLICA).

Segundo o Sr. Pedro o Instituto Cooperforte não faz uso de leis de incentivos fiscais em sua carga tributária. Isto se deve ao fato de como já ser uma OSCIP, já possuir isenção do imposto de renda.

Quando perguntado sobre as dificuldades que a Cooperforte enfrenta, através do Instituto Cooperforte, no desempenho da responsabilidade social ele diz:

O maior desafio do Instituto como Entidade do Terceiro Setor é desmistificar a má visão da população em relação às ONGs. 
A segunda empresa entrevistada foi a Corpore BR. A entrevista foi respondida pela Sra. Kamilla Farias, assistente de comunicação da empresa e atuante na área de responsabilidade social.

Segundo a Sra. Kamilla, a empresa que é do ramo de gestão em ativos imobiliários, se considera capaz de influenciar outras empresas e públicos dos estabelecimentos que administra por todo o país por praticar ações socialmente responsáveis. Ela continua:

Como formadora de opinião ela (Corpore BR) quer propagar o desenvolvimento
sustentável por meio de suas atividades de responsabilidade socioambiental. Em
março de 2007 , a Corpore BR associou-se ao Instituto Ethos de Empresas e
Responsabilidade Social. A empresa passou a ter a orientação de articuladores do
Instituto para auxiliar a gestão de seus negócios de forma socialmente sustentável.
A Corpore BR fundamenta-se nos Indicadores Ethos de responsabilidade social
para avaliar e realizar suas ações na área. [...] Desde a associação, ela participa
de reuniões regionais mensais temáticas com troca de informações com outras
empresas associadas ao Ethos e especialistas no tema abordado em cada encontro,
além de fazer parte de palestras e conferências internacionais voltadas para
responsabilidade social empresarial.

De fato, o contato da empresa Corpore BR, foi conseguido através do Instituto Ethos, pois a mesma está cadastrada entre as poucas empresas do Distrito Federal, associadas ao Instituto.

A Corpore BR aderiu em 2007 ao Pacto Global (vide p.23), se comprometendo com os dez princípios propostos pela Organização das Nações Unidas às organizações empresariais. Entre esses princípios, citados pela própria Sra. Kamilla na entrevista estão: eliminar todas as formas de trabalho forçado ou compulsório; erradicar efetivamente o trabalho infantil; eliminar a discriminação no emprego e na ocupação; combate à corrupção em todas as suas formas, inclusive extorsão e propina, entre outras.

$\mathrm{Na}$ entrevista a Sra. Kamilla também salientou que as atividades sócio-ambientais desenvolvidas pela empresa tem o potencial de gerar, além de benefícios à sociedade e ao meio ambiente, credibilidade da imagem corporativa.

Sobre isso, Soares (2004) escreveu que o direcionamento das empresas para uma nova postura em relação ao social, se deve, entre outras coisas, à competitividade típica do regime capitalista, que vem sendo reforçada pelo fenômeno da globalização.

Nesse contexto, a sobrevivência da empresa depende da vantagem comparativa que ela consiga obter em relação a seus concorrentes, para o que, a legitimidade, a boa imagem corporativa e a maior visibilidade no mercado decorrentes da adoção de programas de responsabilidade social-corporativa são essenciais. (SROUR 1998 apud SOARES 2004 p. 9)

Garay (2004) apud Soares (2004) diz que com essa afirmação pode-se dizer que o posicionamento socialmente responsável da empresas representa uma estratégia de marketing, 
pois garante um diferencial competitivo, junto aos clientes, a sociedade, e aos trabalhadores, reforçando o comprometimento e a identificação com a organização.

Segundo a representante da empresa Corpore BR, as dificuldades enfrentadas no desempenho destas práticas englobam o público que cerca a empresa que é diverso em termos de consciência socioambiental e nem sempre está disposto a aprovar, patrocinar ou participar de medidas de caráter sócio-ambiental. Com isso verifica-se que tais práticas, embora positivas, ainda não são totalmente aceitas nem bem vistas por alguns, o que ainda é um entrave a ser superado pela Corpore BR e pelas demais empresas.

Mas a empresa tem consciência que sua marca tem um diferencial devido as práticas sócio-ambientais desempenhadas, segundo a Sra. Kamilla:

Na minha opinião a empresa (Corpore BR) é melhor vista do que outra similar do
mesmo ramo porque a crescente conscientização das sociedades a respeito do
desenvolvimento sustentável, impulsiona a demanda por empresas que possuam em
seu escopo de atuação a responsabilidade socioambiental.

Em relação ao papel da sociedade civil, no incentivo das práticas de responsabilidade social empresarial, em especial sob a ótica da empresa Corpore BR, ela disse:

\begin{abstract}
A sociedade civil deve ter uma ação participativa em todas as atividades políticas e sociais. Uma maneira de contribuir com a responsabilidade social das empresas é utilizando os critérios de sustentabilidade ao escolher os produtos e serviços, assim exigirá que as empresas mudem suas posturas e conceitos agindo em prol do desenvolvimento sustentável.
\end{abstract}

A empresa não utiliza de leis incentivos fiscais em suas práticas, mas acredita que para muitas empresas esses incentivos sejam cruciais para a manutenção das ações sociais. É o caso da terceira empresa que será analisada mais adiante, do ramo de turismo.

Sobre o fato da empresa Corpore BR, não fazer uso de incentivos fiscais (vide p.34 e 35) em suas práticas de responsabilidade sócio-ambientais, Peliano (2001) escreveu que os incentivos, como os para investimentos em entidades filantrópicas e/ou no Fundo da Criança e do Adolescente, etc., pouco têm contribuído para ampliar os recursos aplicados pelas empresas na área social.

Nas empresas pesquisadas (no trabalho de Peliano) $73 \%$ responderam que os incentivos fiscais não são importantes na decisão de fazer ação social para a comunidade, e apenas 35\% afirmaram ter feito uso, no ano de 1999, de incentivos fiscais para financiar a ação social que realizaram (PELIANO 2001 p. 73) 


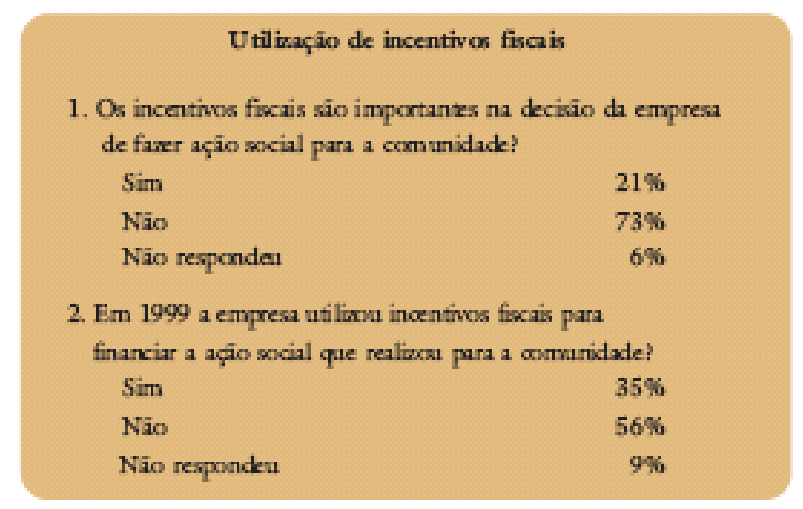

Fonte: Peliano (2001) p. 73

Figura 12: Utilização de incentivos fiscais.

Um empresário do setor farmacêutico argumentou na pesquisa de Peliano (2001):

São muito poucos (os incentivos). São burocráticos [...] os incentivos poderiam ser importantes mas não são. (PELIANO 2001 p. 73).

Rodrigues (2005) escreveu que os incentivos fiscais são estímulos criados pelos Governos para desenvolver e estimular, por meio de parcerias com a iniciativa privada, setores de interesse para o país.

No Brasil tem um histórico de baixa utilização e estão na sua maior parte direcionadas para atividades culturais, os fiscais direcionados especificamente para o terceiro setor são poucos expressivos, tanto em opções quanto em valor da renúncia fiscal (RODRIGUES 2005 p. 10).

Machado (2005) continua citando pesquisa feita pela Federação das Indústrias do Estado de São Paulo (FIESP) realizada com quinhentos e quarenta e três associados em 2003, que detectou que boa parte da indústria faz pouco uso dos incentivos fiscais, alguns dados desta pesquisa são descritos a seguir:

- Dedução de doações para entidades sem fins lucrativos: 40,7\% das empresas não usa, mas conhece os incentivos, e 38,7\% não usa e não conhece os incentivos.

- Dedução para doações/patrocínios a projetos culturais: 8,5\% das empresas fazem dedução; 55,8\% não usa, mas conhece os incentivos; 35,7\% não usa e não conhece os incentivos.

- Dedução de doações aos Fundos dos Direitos da Criança e do Adolescente: 11,4\% das empresas fazem a dedução; 46,3\% não usa, mas conhece os incentivos; 42,3\% não usa e não conhece os incentivos (MACHADO 2005 p. 35)

Verifica-se que muitas empresas preferem não utilizar os benefícios fiscais previstos em lei, ou por desconhecimento, ou porque consideram que não compensa.

Sobre isso Machado (2005) escreveu: 
Em pesquisa do IPEA feita em 2002 foi apurado que "somente 6\% das empresas que atuam no social declararam recorrer às isenções fiscais permitidas pela legislação federal do Imposto de Renda em suas ações sociais, o que no entender dos pesquisadores confirma que a política de benefícios tributários em pouco contribui para promover as ações sociais privadas. [...] pode-se criticar que as atuais leis de incentivo não tem como serem usadas em todos os projetos sociais, que elas precisam ser aperfeiçoadas, que são confusas e burocráticas. No entanto, não podemos deixar de reconhecer que mesmo com todas suas deficiências elas podem ser usadas sim, numa quantidade enorme de ações sociais viabilizando ou ampliando de forma direta ou indireta muitos projetos. As empresas por incrível que pareça não sabem disso. (MACHADO 2005 p. 36).

Sobre as leis de incentivos fiscais na motivação das empresas, para o exercício das práticas de responsabilidade social, a empresa Corpore $\mathrm{BR}$, embora não utilize estes incentivos considera tais leis importantes:

Segundo o tripé da sustentabilidade a empresa deve ser financeiramente viável, socialmente justa e ambientalmente responsável, tem que ter equilíbrio nas três áreas. É necessário ter capital para realizar as ações, o incentivo fiscal facilita as empresas comprometidas, a realizarem os projetos de RSE. (Sra. Kamilla Farias representante da Corpore BR).

A empresa Corpore BR, também respondeu uma questão relacionada à satisfação no desempenho da responsabilidade social pela empresa:

Temos tido boas respostas de nossos stakeholders, porém ainda há muito o que fazer. Somos uma empresa de médio porte da capital fechado, estamos em processo de evolução, buscando aprimorar nossas ações e alcançar maiores resultados.

Em todas as entrevistas aplicadas, em uma das questões, foi citada uma afirmação da socióloga do IPEA, já mencionada neste trabalho, Anna Maria Peliano (2009), que em uma de suas pesquisas afirmou:

"Entre as grandes empresas que avaliam sua atuação no campo social, a maioria declaram ter como objetivo melhorar sua imagem, em segundo lugar elas buscam aumentar a satisfação dos empregados e em terceiro lugar elas se preocupam em complementar a ação do governo" (PELIANO 2009 p. 42).

Baseado nesta informação foi perguntado às empresas se, na opinião delas, isso realmente reflete a realidade, baseado no que elas vivenciam em suas empresas. A Sra. Kamilla da Corpore BR respondeu:

As pressões econômicas e sociais causadas pela deficiência do atual sistema capitalista e do Estado, que não consegue suprir as necessidades básicas da população, levaram algumas organizações a se preocuparem não só com as responsabilidades econômicas e legais, mas também com as suas responsabilidades éticas, morais e sociais, e, após tantas catástrofes naturais, conseqüentes do mau uso dos recursos, a população mundial passou a "refletir melhor" sobre suas ações e consumo exacerbado. Infelizmente ainda há um número pequeno de empresas que incorporam essa responsabilidade em seu escopo, e outras levam essa responsabilidade como mero discurso de marketing .A Corpore BR acredita que o papel das empresas, como formadoras de opinião $e$ responsáveis pela atividade econômica mundial, é contribuir para a solução dos problemas de base da sociedade. 
Nesta mesma questão a empresa do ramo de turismo respondeu:

No caso da nossa empresa, a complementaridade da ação do governo vem em primeiro lugar, seguido da melhoria da imagem e, por último, aumentar a satisfação dos empregados. Tanto é verdade que o programa Férias do Trabalhador Brasileiro é considerado como um dos projetos com maior potencial (da empresa) no atual momento.

Já o Sr. Pedro do Instituto Cooperforte disse:

Isso se deve ao fato de que a grande maioria (das empresas), serem capitalistas e pertencerem a uma sociedade também capitalista.

$\mathrm{Na}$ opinião do representante do Instituto Cooperforte, as empresas que pensam dessa forma (citada por Peliano 2009), buscam melhorar a sua imagem empresarial através da responsabilidade social e não a praticam porque se preocupam com as causas, elas pensam somente em aumentar seus lucros, através da melhoria de sua imagem, o que segundo ele não é o caso da Cooperforte.

Obviamente as empresas (fora do anonimato) não assumiriam que o principal motivo, do exercício das práticas de responsabilidade social seria melhorar sua imagem, embora assumam, como já citado (Corpore BR), que ao exercerem tais práticas a imagem delas é melhor percebida pela sociedade, comparando-se com outras empresas similares que não exercem.

A terceira empresa analisada foi do ramo do turismo, ela tem como missão promover a inclusão social. É um clube de turismo sob a forma de associação sem fins lucrativos, focado nas classes B e C. A empresa segue a legislação do terceiro setor, por ter natureza jurídica de uma empresa sem fins lucrativos. Ela é imune da cobrança de imposto de renda. Segundo o Sr. Gestor da empresa, ela possui essa isenção por não remunerar os investidores. Segundo o site da Receita Federal estão isentas do imposto de renda as instituições de educação e as de assistência social, sem fins lucrativos, além de outras. Reforçando, a lei $\mathrm{n}^{\circ}$ 9.532/97 considera imune:

A instituição de educação ou de assistência social que preste os serviços para os quais houver sido instituída e os coloque à disposição da população em geral, em caráter complementar às atividades do Estado, sem fins lucrativos (RECEITA FEDERAL).

. O entrevistado continua:

É absolutamente fundamental que haja incentivos nesse sentido para estimular a criação de organizações que atuem em prol do bem-estar da sociedade, complementando ações governamentais. $O$ Estado deve prestigiar esse tipo de iniciativa, já que tais empresas auxiliam na execução de práticas que vão ao encontro dos seus objetivos. Entretanto, é necessário que sejam criados mecanismos para evitar o uso inadequado desse benefício.

A empresa citou outro beneficio oriundo do setor público utilizado em suas atividades: 
Outro benefício oriundo do setor público é o apoio do Ministério do Turismo a projetos que estimulem essa prática do turismo social por intermédio dos clubes de turismo. Exemplo disso é a concretização do Programa "Férias do Trabalhador Brasileiro" (Mais informações: www.feriasdotrabalhador.com.br).

Sobre as dificuldades que a empresa enfrenta, segundo o entrevistado é a ausência de pessoas interessadas em compor o quadro societário e investir no negócio. Além do que, segundo ele, o ramo de clubes de turismo social ainda é pouco conhecido como integrante do meio turístico nacional.

Em relação ao papel da sociedade civil, no incentivo das práticas de responsabilidade social, principalmente pela empresa (de turismo) o entrevistado respondeu:

O empreendedorismo social é uma atividade fundamental para o desenvolvimento
amplo da sociedade, constituindo-se como um dos pilares para o atendimento das
necessidades das pessoas como um todo. Governo e mercado, ou seja, primeiro e
segundos setores possuem capacidades limitadas para equacionar certas
demandas sociais, exigindo a existência de organizações que visem suprir essas
limitações. Acreditamos que determinadas ações e medidas que visem à melhoria
de determinados setores, como o turismo, só terão efeito imediato por meio dessas
empresas.

As características das empresas com cunho social são diferentes das empresas privadas, que visam o lucro. Exemplo na figura 13:

\begin{tabular}{|c|c|}
\hline Empreendedorismo privado & Empreendedorismo social \\
\hline 1. É individual & 1. É coletivo \\
\hline 2. Produz bens e serviços para o mercado & 2. Produz bens e serviços para a comunidade \\
\hline 3. Tem o foco no mercado & $\begin{array}{l}\text { 3. Tem o foco na busca de soluções para os } \\
\text { problemas sociais }\end{array}$ \\
\hline 4. Sua medida de desempenho é o lucro & $\begin{array}{l}\text { 4. Sua medida de desempenho é o impacto } \\
\text { social }\end{array}$ \\
\hline $\begin{array}{l}\text { 5. Visa satisfazer necessidades dos clientes e } \\
\text { ampliar as potencialidades do negócio }\end{array}$ & $\begin{array}{l}\text { 5. Visa resgatar pessoas da situação de risco } \\
\text { social e promovê-las }\end{array}$ \\
\hline
\end{tabular}

Fonte: Melo Neto e Froes (2002, p. 11) in Rossoni et al. (2006) apud Lima (2008)

.Figura 13: Empreendedorismo privado x empreendedorismo social

Dees (1998) apud Lima (2008) descreve a empresa social como empreendimentos de negócios de propósitos sociais, são as organizações hibridas - porque juntam elementos sem fins lucrativos com elementos com fins de lucro,como abrigos de sem teto que promovem pequenos negócios para manter e empregar seus residentes, ou como clubes de turismos, caso da empresa estudada nesta monografia. Eles não deixam de ser uma empresa, apesar de desenvolverem atividades sociais. 
A empresa (de turismo) considera que tem alcançado seus objetivos e que tem contribuído para o alcance do objetivo mais amplo da empresa, que é proporcionar momentos de lazer para todas as pessoas independente das condições sócio-econômicas.

No caso da pesquisa realizada é importante frisar: a empresa Corpore BR pratica ações de responsabilidade social voluntariamente e sem retorno fiscal. Ela não possui um Instituto, ou uma Fundação como no caso da Cooperforte que possui o Instituto Cooperforte. O Instituto Cooperforte é regido pela lei nº 9.790 de 1999, é uma OSCIP. As OSCIPs possuem imunidade de imposto de renda, fato regido pela lei $n^{\circ}$ 9.532/97. A Cooperforte empresa, segundo o entrevistado, não se utiliza dos incentivos fiscais, como os oriundos dos Fundos dos Direitos da Criança e do Adolescente, Doações a Entidades de Ensino Superior, entre outros já citados (vide p.30 e 31) Ela mantêm o Instituto Cooperforte, que por ser OSCIP é isenta de imposto de renda. Já a empresa do ramo de turismo também possui isenção de imposto de renda por também ser uma OSCIP.

O Setor Público influência as práticas das empresas, através das leis que regulamentam o Terceiro Setor. Também, o Setor Público influencia as práticas de uma empresa através das leis de incentivos fiscais. Mesmo se a empresa não usufruir das leis que regulamentam o Terceiro Setor e nem utilizar os incentivos fiscais existentes em seus projetos, ela é aliada do Estado, na medida em que, busca complementar as políticas públicas estatais. De fato, tais empresas colaboram na melhoria do desempenho social de muitas comunidades.

Rico (2004) citou Senna (2001) que argumentou que a nova política de desenvolvimento deve ser basear na busca incansável da transformação produtiva com equidade social.

A nova ética é a da co-responsabilidade dos grandes setores da vida brasileira (governo, mundo empresarial e terceiro setor) no enfrentamento das desigualdades sociais intoleráveis (p.78)

Amcham (2003) apud Rico (2004) continuou que conhecer os programas governamentais é um passo fundamental nesse processo, a partir do qual a empresa pode identificar oportunidades de inserção, por meio da disponibilização de recursos. [...] Ao atuar alinhada às políticas públicas, a empresa pode contribuir para o fortalecimento do papel do Estado, na busca de soluções efetivas para os problemas sociais existentes.

Todavia diante das implicações que a questão social tem colocado ao Estado, ao mercado e à sociedade civil, entende-se que, embora contraditórios (pois o empresariado possui seus próprios interesses, tais como vantagem competitiva, visibilidade nos negócios e divulgação de imagem), os investimentos sociais empresariais revelam um compromisso público do empresariado no enfrentamento 
das desigualdades sociais, buscando colaborar com o desenvolvimento social sustentável .(RICO 2004 p. 81).

A empresa de turismo analisada neste trabalho, como exemplo, é juntamente com o Governo co-responsável pela inserção de populações de renda mais baixa no turismo nacional, oferecendo meios para que elas possam realizar viagens mais baratas. Essa parceria com o governo é um exemplo de influencia que o Setor Público pode ter sobre as empresas ou as entidades de Terceiro Setor que possuem ações sociais objetivando incrementar ou complementar alguma política pública. 


\section{CONSIDERAÇÕES FINAIS}

Neste trabalho foi possível observar o papel do Setor Público representado pelo Estado e pelo Governo nas práticas da responsabilidade social empresarial. Através de incentivos fiscais e leis que regulamentam o Terceiro Setor, o Estado colabora com tais práticas. Além disso o próprio Estado, e sua ineficácia de suprir adequadamente as demandas sociais por educação, saúde, lazer, cultura, etc., levam as empresa a se conscientizarem que o papel delas no desenvolvimento social também é importante. Elas sentem a necessidade ética e social de aplicar parte de seus lucros em projetos, programas, Institutos, Fundações, ONGs que desempenham ações sócio-ambientais, complementando, e não substituindo, as políticas públicas e as ações do Governo.

Vários autores definem responsabilidade social e descrevem as características destas práticas no Brasil. Este estudo é importante para observar a realidade da Responsabilidade Social Empresarial, e o impacto que as empresas, as Organizações não Governamentais e/ou o Terceiro Setor exercem no desenvolvimento do país. Entender como ocorreu o crescimento destas atividades, e o porquê deste crescimento é importante não somente para o estudo da história e das características da Responsabilidade Social Empresarial no Brasil, mas também para entender porque a preocupação com o social faz parte da sociedade brasileira, sociedade esta formada pelos setores: Primeiro (Estado), Segundo (Mercado) e Terceiro (OSCIPs, ONGs, sociedade civil, etc.).

A sociedade civil que também abrange os clientes, consumidores, stakeholders das empresas e a sociedade organizada ou não, incluindo aí, todas as pessoas, os cidadãos, as crianças, os formadores de opinião, etc., influenciam as empresas nas suas práticas sociais, porque estão cada vez mais exigentes, não basta para um empresa gerar empregos, ou fornecer um produto de qualidade. Ela precisa, e isso tem sido cada vez mais cobrado, exercer ações que colaborem mais com o desenvolvimento social das pessoas e das comunidades.

A sociedade civil também influencia as práticas de responsabilidade social das empresas na medida em que demanda por serviços essenciais que não são devidamente supridos pelo Estado através de suas políticas públicas. Obviamente, se não existisse uma causa a ser suprida, uma grupo vulnerável para se ajudar, tais práticas não seriam necessárias. As pessoas e o desenvolvimento humano e pessoal que elas necessitam, mas que muitas vezes não conseguem por si mesmas suprirem adequadamente, motivam as empresas a investirem cada vez mais em ações sociais. 
Pelo histórico da responsabilidade social empresarial observa-se que essas praticas aumentaram na década de 1990, década na qual mudanças significativas ocorreram na administração pública no Brasil. Foi interessante observar esta ligação e futuros estudos sobre a relação entre a evolução da administração pública, mudanças de governos e as práticas de responsabilidade social seriam válidos.

A competitividade entre as empresas, e a busca constante pela visibilidade da marca é um dos motivos que levam as empresas a exercerem atividades de responsabilidade social, seja por conta própria, ou através de parcerias ou doações a entidades do Terceiro Setor. Muitas empresas não admitem que tem como objetivo principal melhorar sua imagem, mas concordam que a marca ganha uma credibilidade extra com a adoção de práticas sociais.

Foi interessante observar também que todas as empresas sejam elas micro, pequenas ou grandes adotam a responsabilidade social em suas atividades. A RSE não se restringe às grandes empresas, que possuem em muitos casos, seus próprios Institutos ou Fundações. As micro e pequenas empresas ajudam com doações, programas, projetos entre outras atividades.

A maioria das empresas, segundo a literatura, não utiliza os incentivos fiscais, principalmente os de cunho social, como o Funcriança e as Doações às OSCIPS, porque os descontos financeiros no imposto de renda ainda são baixos. Estudos futuros, com um número maior de empresas, seriam interessantes para analisar este fato. 


\section{REFERÊNCIAS}

AITH, Márcio; GUANDALINI, Giuliano Os santos do capitalismo- a doação do investidor Warren Buffett à fundação Bill Gates é o maior exemplo de como o capitalismo americano consegue não só gerar riquezas astronômicas como também devolvê-las à sociedade. Revista Veja. São Paulo, 05 de jul. de 2006. Ano 39, n. 26, p. 60 a 69. Disponível em: http://veja.abril.com.br/050706/p_060.html

ALMEIDA, Filipe Jorge Ribeiro de. Ética e desempenho social das organizações: um modelo teórico de análise dos fatores culturais e contextuais. Rev. adm. contemp., Curitiba, v. 11, n. 3 , Sept. 2007 Disponível em: http://www.scielo.br/scielo.php?script=sci_arttext\&pid=S141565552007000300006\&lng=en\&nrm=iso>. Acesso: Julho 2010.

ÁREAS de atuação. Instituto Sabin. Disponível em: http://blog.institutosabin.org.br/quemsomos-2/areas-de-atuacao/. Acesso: Junho de 2010.

BEZERRA, Douglas Moraes; CUNHA, Allen A. da Costa; MARTINS, Igor; SOUZA, Rísia K. Santana; FERREIRA, Antônio V. Oliveira - Descentralização do Poder Público: Gerencialismo X Gestão Participativa. Universidade Estadual do Piauí - UESPI. Revista UESPI Vol. $\quad 1 \quad n \quad$ n $2009 . \quad$ Disponível em: http://www.uespi.br/revista/pdf/v1n2/artigo_08_v1_n2_2009.pdf Acesso: Julho 2010.

BRASIL. Decreto $\mathrm{n}^{\circ}$ 3.100, de 30 de junho de 1999. Presidência da Republica, Casa Civil, Subchefia para assuntos jurídicos, Poder Executivo, Brasília-DF. Disponível em: http://www.planalto.gov.br/ccivil_03/decreto/d3100.htm Acesso: agosto de 2010.

BRASIL. Lei $n^{\circ}$ 9.532, de 10 de dezembro de 1997. Ministério da Fazenda, Receita Federal, Poder Executivo, Brasília - DF, dezembro de 1997. Disponível em: http://www.receita.fazenda.gov.br/legislacao/Leis/Ant2001/lei953297.htm. Acesso: Junho 2010. 
BRASIL. Lei $\mathrm{n}^{\circ}$ 9.637, de 15 de maio de 1998. Presidência da Republica, Casa Civil, Subchefia para assuntos jurídicos, Poder Executivo, Brasília-DF. Disponível em: http://www.planalto.gov.br/ccivil_03/Leis/L9637.htm Acesso: Junho de 2010

BRASIL. Lei n ${ }^{\circ}$ 9.790/99, de 23 de março de 1999. Presidência da Republica, Casa Civil, Subchefia para assuntos jurídicos, Poder Executivo, Brasília-DF. Disponível em: http://www.planalto.gov.br/ccivil_03/Leis/L9790.htm Acesso: Junho de 2010

BRASIL. Regulamento do Imposto de Renda de 1999 - Decreto 3000/99 | Decreto No 3.000, de 26 de Março de 1999. Diário Oficial da República Federativa do Brasil, Poder Executivo Brasília- DF, 26 de março de 1999. Disponível em: http://www.jusbrasil.com.br/legislacao/110446/regulamento-do-imposto-de-renda-de-1999decreto-3000-99. Acesso: Junho de 2010.

BUFONI, André Luiz; MUNIZ, Natiara Penalva; FERREIRA, Aracéli Cristina de Sousa - O processo de Certificação Socioambiental das Empresas: o Estudo de Caso do Certificado 'Empresa Cidadã' - RAC, Curitiba, v.13, Edição Especial, art. 2, p. 19-38, Junho 2009. Disponível em: www.anpad.org.br/rac. Acesso: Junho 2010.

COUTINHO, Renata Buarque Goulart; MACEDO-SOARES, T. Diana L. v. A.. Gestão estratégica com responsabilidade social: arcabouço analítico para auxiliar sua implementação em empresas no Brasil. Rev. adm. contemp., Curitiba, v. 6, n. 3, Dec. 2002.

CRUZ, Jardson Saraiva - Algumas Considerações sobre a Tributação do Terceiro Setor. FEMICE-Federação das Misericórdias e Entidades Filantrópicas do Ceará, 2006. Disponível em: http://www.femice.org.br/artigos/artigo170206.doc. Acesso: Junho de 2010.

EMPRESAS associadas. Instituto Ethos. Disponível em: http://www1.ethos.org.br/EthosWeb/pt/1937/destaque_home/participe/empresas_associadas.a spx. . Acesso: junho de 2010.

EMPRESAS associadas (our members list). Instituto Ethos. Disponível em: http://www.ethos.org.br/sistemas/empresas_entidades/empresas_associadas/lista_geral/index. asp. Acesso: junho de 2010. 
ENSINO Fundamental. Fundação Bradesco. Disponível em: http://www.fb.org.br/Institucional/SegmentosEducacionais/EnsinoFundamental/. Acesso: junho de 2010.

ENTIDADES imunes e isentas. 024 - Quais as pessoas imunes do imposto de renda que estão sujeitas à entrega da DIPJ? Receita Federal. Disponível em:

http://www.receita.fazenda.gov.br/pessoajuridica/dipj/2005/pergresp2005/pr24a31.htm Acesso: agosto de 2010.

GARCIA, Bruno Gaspar - Responsabilidade Social Empresarial, Estado e Sociedade Civil: o caso do Instituto Ethos - Universidade Estadual de Campinas - UNICAMP. Campinas, 200 ?. Curso: Ciências Sociais, Orientadoras: Profa. Evelina Dagnino e Profa. Raquel Negrão.

GIAMBIAGI, F. \& ALÉM, Ana Cláudia, Finanças Públicas: teoria e prática no Brasil. Ed. Campus. 2008

GONÇALVES, Ernesto Lima - Mecanismos Sociais na Gestão Empresarial: para além de uma vã filosofia; RAE, vol. 20; páginas 59-65. Rio de Janeiro, outubro/dezembro 1980.

INDICADORES ETHOS de responsabilidade social empresarial - Apresentação da versão 2000; Instrumento de avaliação e planejamento para empresas que buscam excelência e sustentabilidade em seus negócios, 2000.

INVESTIMENTO. Fundação Bradesco. Disponível em: http://www.fb.org.br/Institucional/InvestimentoseResultados/Investimentos/. Acesso: junho de 2010.

KOTLER, Philip, KELLER, Kevin Lane. Administração de Marketing. 12 ed. São Paulo, editora: Pearson - Prentice Hall, 2006.

LIMA, Ana Carolina Garcia Rodrigues - Empreendedorismo Social: Oportunidades e Competências a serem exploradas. Monografia de Conclusão de Curso - Administração de Empresas, Universidade de Brasília - UnB, 2008. 
MACHADO Filho, Cláudio Pinheiro. Responsabilidade Social e Governança - o debate e as implicações. 1 ed. São Paulo, editora: Pioneira Thomson Learning, 2006.

MÂNICA, Fernando Borges - Panorama histórico-legislativo do Terceiro Setor no Brasil: do conceito de Terceiro Setor à Lei das OSCIP in OLIVEIRA, Gustavo Justino (Coordenador) Terceiro Setor Empresas e Estado - novas fronteiras entre o público e o privado. Belo Horizonte, Editora Fórum, 2007.

NEGÓCIOS Sociais sustentáveis - estratégias inovadoras para o desenvolvimento social Ashoka empreendedores sociais, McKinsey \& Company - São Paulo: Peirópolis, 2006.

NOGUEIRA, Antonio Adias - Setor Público. EGSP - Instituto de Ciências Sociais e Comunicação - Universidade Paulista UNIP - 2009. Disponível em: http://novosolhos.com.br/site/arq_material/11592_12573.pdf Acesso: Julho 2010.

OLIVEIRA, José Lourival, SCHWERTNER, Isadora Minotto Gomes - Breve análise das práticas de responsabilidade social empresarial e a concessão de incentivos governamentais em âmbito federal. Universidade Federal de Santa Catarina. 2007. Disponível em: http://www.buscalegis.ufsc.br/revistas/index.php/buscalegis/article/viewFile/9385/8951. Acesso: Junho de 2010.

O PAI do choque de gestão - para o formulador da reforma gerencial do Estado, é questão de tempo: os países terão de adotar a reforma gerencial, para prestar serviços com eficiência. Por Carlos Costa. Bresser Pereira. Disponível em: http://www.bresserpereira.org.br/Papers/Interviews/2010/Entrevista_Bresser-Pereira.pdf Acesso: Julho de 2010.

OS DEZ MANDAMENTOS da Responsabilidade Social, por Stephen Kanitz. Disponível em: http://www.filantropia.org/artigos/kanitz_responsabilidade_social.htm. Acesso: Junho de 2010. 
PELIANO, Anna Maria T. Medeiros (coord.) - Bondade ou Interesse?Como e por que as empresas atuam na área social. Brasília, IPEA, 2001.

PELIANO, Anna Maria T. Medeiros (coord.) - Cultivando os Frutos Sociais - A importância da Avaliação nas Ações das Empresas , Brasília IPEA, 2009. Disponível em: http://www.ipea.gov.br/sites/000/2/livros/2009/Livro_Cultivando_Frutos_Sociais.pdf Acesso: maio/junho/julho 2010.

PINHEIRO, Paulo Sérgio -O Conceito de Sociedade Civil. PUC- Rio, 200?. Certificação Digital $\quad \mathrm{n}^{\circ} \quad$ 0310315/CA. Disponível em: $\underline{\text { http://www2.dbd.puc- }}$ rio.br/pergamum/tesesabertas/0310315_05_cap_04.pdf. Acesso: Julho 2010.

PINTO, Marcelo de Rezende; LARA José Edson - A cidadania corporativa como uma orientação de marketing: um estudo no varejo; RAE, vol. 44; página 48 - Edição especial Minas Gerais, 2004

QUEIROZ, Adele. A responsabilidade social das empresas no Brasil: um estudo sobre indicadores. V Congreso Internacional Del CLAD sobre la Reforma del Estado y de La Administración Pública, Santo Domingo, Rep. Dominicana, 24-27 Oct. 2000

QUEM somos. Fundação Bradesco http://www.fb.org.br/Institucional/FundacaoBradesco/QuemSomos/. Acesso: junho de 2010.

QUEM somos. Instituto Sabin. Disponível em: http://blog.institutosabin.org.br/quem-somos2/. Acesso: junho de 2010.

QUEM somos. Instituto Cooperforte. Disponível em: http://www.institutocooperforte.org.br/opencms/instituto/historia/ Acesso: agosto de 2010.

REETZ, Lucimar; TOTTOLA, Etienne de Castro. Responsabilidade Social - Impossível ficar de fora. 2 ed. São Paulo: Editora Livro Pronto, 2006. 
RELATÓRIO de gestão 2008. Fundação Banco do Brasil, 2009. Disponível em: http://www.fbb.org.br/portal/pages/publico/relatoriogestao/2008/Relatorio2008.pdf Acesso: Junho de 2010.

RESPONSABILIDADE social. Corpore BR. Disponível em: http://www.corporebr.com.br/conteudo.php?area=RESPONSABILIDADE Acesso: agosto de 2010.

REZENDE, Fernando, CUNHA, Armando - Contribuintes e cidadãos compreendendo o orçamento federal, Editora FGV, Rio de Janeiro/São Paulo 2002.

RIBEIRO, Liliana Reis; CARVALHO, Andréa; LEITE, Ismene. Responsabilidade Social x Estratégia Competitiva: 02 (dois) estudos de casos: Odebrecht S/A - Fundação Odebrecht e Dow Química. Monografia apresentada ao Núcleo de Pós-Graduação da Universidade Federal da Bahia/ CPA - Capacitação Profissional Avançada como requisito à obtenção do grau de Especialista em Administração. Salvador 2001.

RICO, Elizabeth de Melo. A responsabilidade social empresarial e o Estado: uma aliança para o desenvolvimento sustentável. São Paulo Perspec., São Paulo, v. 18, n. 4, Dec. 2004 . Disponível em: http://www.scielo.br/scielo.php?script=sci_arttext\&pid=S010288392004000400009 Acesso: maio de 2010.

RODRIGUES, Luiz Fernando Rocha - Incentivos Fiscais: uma reflexão sobre a baixa utilização em projetos socioculturais. Universidade Federal do Rio de Janeiro - UFRJ, Instituto de Economia, MBE em Responsabilidade Social e Terceiro Setor. Agosto de 2005.

ROESCH, Sylvia Maria Azevedo. Projetos de estágio e de pesquisa em administração guia para estágios, trabalhos de conclusão, dissertações e estudos de caso. 03 ed. São Paulo, editora: Atlas, 2006.

ROMANIELLO, Marcelo Márcio e AMÂNCIO, Robson - Gestão Estratégica e a responsabilidade social empresarial: um estudo sobre a percepção dos estudantes do curso de administração. REAd, edição 45, volume 11, n 3 maio/junho 2005. 
SÁ, Analice Erthal Corrêa - A Contribuição das Pequenas Empresas na Promoção da

Responsabilidade Social - Universidade de Brasília, 2003.

SOARES, Carla; CARVALHO, Ana Paula - Terceiro Setor: em busca de um marco teórico. Anais do II Seminário Nacional - Movimentos Sociais, Participação e Democracia. 25-27 de abril de 2007, UFSC, Florianópolis, Brasil. Núcleo de Pesquisa em Movimentos Sociais - NPMS. Disponível em: http://www.sociologia.ufsc.br/npms/carla_soares_ana_paula_carvalho.pdf. Acesso: Julho 2010.

SOARES, Gianna Maria de Paula. Responsabilidade social corporativa: por uma boa causa!?. RAE electron., São Paulo, v. 3, n. 2, Dec. 2004 . Disponível em: http://www.scielo.br/scielo.php?pid=S1676-56482004000200007\&script=sci_arttext Acesso: Junho de 2010.

SOUZA, Juliana Sturmer Soares de Souza; NASSIF, Vânia Maria Jorge. Convergências e Divergências de perfis profissionais: comparando os desafios $e$ as ações do empreendedor social em relação ao empreendedor de negócios. XI SemeAd empreendedorismo em organizações. Agosto de 2008. Disponível em: http://www.ead.fea.usp.br/semead/11semead/resultado/an_resumo.asp?cod_trabalho=692.

Acesso: Junho de 2010.

TREVISAN, Fernando augusto. Balanço Social como instrumento de marketing. Fundação Getúlio Vargas - Escola de administração de empresas de São Paulo. RAE - eletrônica, vol. 1, núm. 02, jul./dez. 2002. Disponível em: http://www16.fgv.br/rae/artig os/1465.pdf Acesso: Junho de 2010.

VEIGA NETO, Alípio Ramos; PANHOSSI, Kelly Regina; GODOY, Ana Flávia Moreira Responsabilidade Social em empresas privadas e sua relação com o terceiro setor. REAd Edição 39, vol. 10; n 3; Maio/Junho 2004.

VERGARA, Sylvia Constant e BRANCO, Paulo Durval; Empresa humanizada: a organização necessária e possível. RAE abril/junho 2001; São Paulo, vol. 41 n. 2; p. 20-30 
